\title{
PERAN SULTAN MUHAMMAD MULIA IBRAHIM SYAFIUDDIN DI KESULTANAN SAMBAS 1931-1943 DALAM BIDANG REVITALISASI LEMBAGA PERADILAN AGAMA
}

\author{
Beti Yanuri Posha \\ Ahmad M. Sewang \\ Siti Aisyah H. Kara \\ Arifuddin Siraj \\ Institut Agama Islam Sultan Muhammad Syafiuddin Sambas \\ betiyanuriposha@gmail.com
}

\begin{abstract}
Abstrak: Sambas adalah salah satu Kesultanan Melayu yang cukup lama eksis di tanah Borneo. Kerajaan Islam Sambas atau yang disebut Kesultanan Sambas berdiri pada paruh kedua pertengahan abad ke-17 M. Kesultanan Sambas terkenal besar sejak sultan Sambas yang pertama Sultan Muhammad Syafiuddin I (16311668 M). Kejayaan Kesultanan Sambas telah membesarkan nama negeri Sambas, sampai pada Sultan Sambas ke-15 yaitu Sultan Muhammad Mulia Ibrahim Syafiuddin (1931-1943 M).

Raden Muhammad Mulia Ibrahim adalah putra Pangeran Adipati Ahmad bin Sultan Muhammad Syafiuddin II. Pendidikan awal Raden Muhammad Mulia Ibrahim diperolehnya dari lingkungan keluarga terutama pendidikan yang diterapkan oleh kakeknya sendiri Sultan Muhammad Syafiuddin II dan ayahnya Raden Ahmad. Sebelum dinobatkan, pada tanggal 2 Mei 1931 M, Belanda mengikat kontrak politik dengan Sultan Muhammad Mulia Ibrahim Syafiuddin, bahwa penyelenggaraan pemerintahan Kerajaan Sambas harus menyesuaikan diri dengan ketentuan yang termaktub dalam Staatsblad Pemerintah Hindia Belanda yang disebut dengan Korte Verklaring atau Akte Van Vereband. Kepada sultan sebagai Het Zelfbestuur dikuasakan oleh pemerintah Hindia Belanda antara lain untuk melaksanakan hukum agama Islam dan hukum adat. Adapun peran Sultan Muhammad Mulia Ibrahim Syafiuddin dalam pengembangan Islam meliputi pembaruan di bidang pendidikan Islam, revitalisasi lembaga peradilan agama dan pranata sosial keagamaan. Oleh sebab itu, penting untuk mengetahui dan mengkaji kembali bagaimana peran Sultan Muhammad Mulia Ibrahim Syafiuddin, khususnya dalam revitalisasi lembaga peradilan agama di Kesultanan Sambas 1931-1943.
\end{abstract}

Keyword: Peran Sultan Muhammad Mulia Ibrahim Syafiuddin, Revitalisasi Lembaga Peradilan Agama

\section{PENDAHULUAN}

Kalimantan Barat memiliki kawasan yang luasnya $146,807 \mathrm{~km}^{2}$ atau $7.65 \%$ daripada luas keseluruhan kawasan Indonesia. ${ }^{1}$ Secara geografi, posisi itu menempatkan Kalimantan Barat pada posisi strategis. Jelasnya berada pada jalur perdagangan Laut Cina Selatan dan terlibat dalam arus sejarah Melayu sebelum abad ke-20. Namun, setelah itu tidak banyak informasi tentang penghuni kawasan ini yang

\footnotetext{
${ }^{1}$ Moh. Haitami Salim dkk, "Sejarah Kerajaan Sambas Kalimantan Barat" (Laporan Penelitian) Pusat Penelitian dan Pengabdian pada Masyarakat (P3M) STAIN, Pontianak, 2010), h. 8.
} 
dapat diketahui. Bahkan, dalam sejarah nasional (khususnya yang berkenaan dengan kerajaan-kerajaan yang bercorak Islam), kerajaan Islam di Kalimantan Barat, termasuk sangat jarang dibicarakan. ${ }^{2}$ Sambas, sejak tanggal 15 Juli 1999 telah kembali bangkit menjadi ibukota Kabupaten Sambas. Sebelumnya, kota Sambas hanya menjadi ibukota kecamatan, salah satu kecamatan dalam Kabupaten Daerah Tingkat II Sambas yang beribukota di Singkawang (sejak tahun 1957-1999). Sambas telah menjalin hubungan diplomasi dengan VOC (Vereenigde Oost-Indische Compagnie) melalui kontak dagang yang dilakukan dalam dua tahun (1609 M dan $1818 \mathrm{M})$ di samping diplomasidiplomasi lain yang mengikutinya.

Sambas adalah sebuah kerajaan yang eksis dalam jaringan perdagangan, dapat dilihat dengan kontrak perjanjian dagang antara Raja Sambas tahun 1609 M dalam hal monopoli perdagangan emas. Kerajaan Islam Sambas atau yang disebut Kesultanan Sambas berdiri pada paruh kedua pertengahan abad ke-17 M. Kerajaan Islam Sambas atau yang lebih terkenal dengan sebutan Kesultanan Sambas berdiri pada 10 Zulhijjah 1040 H. Kesultanan Sambas tentu tidak bisa dilepaskan dari keterkaitannya dengan kekuasaan sebelumnya terutama kekuasaan Ratu Sepudak di Kerajaan Sambas Tua, Kerajaan Brunei dan Kerajaan Matan Sukadana. Hubungan terbina baik antara Raja Tengah dengan Ratu Sepudak dan semakin dipererat dengan pernikahan antara anak Ratu Sepudak bernama Mas Ayu Bungsu dengan anak sulung Raja Tengah bernama Raden Sulaiman. Pernikahan Raden Sulaiman dengan Mas Ayu Bungsu memungkinkan penyebaran Islam secara signifikan. Kesultanan Sambas terkenal besar sejak sultan Sambas yang pertama Sultan Muhammad Syafiuddin I (1631-1668 M). Kejayaan Kesultanan Sambas telah membesarkan nama negeri Sambas, sampai pada Sultan Sambas ke-15 yaitu Sultan Muhammad Mulia Ibrahim Syafiuddin (1931-1943 M). ${ }^{3}$

Sejak zaman pendudukan Jepang dan NICA (1942-1950), integritas Kesultanan Sambas telah meredup karena terlibat dengan pergolakan Perang Dunia II. Ketika daerah Sambas atau Kalimantan Barat kembali bernaung dibawah Negara Kesatuan Republik Indonesia pada tahun 1950, dan dibentuknya pemerintahan administratif Kabupaten Sambas, rakyat Sambas sesungguhnya menuntut agar kota Sambas tetap menjadi ibukota Kabupaten Sambas. Keinginan rakyat Sambas ini adalah sebagai upaya melanjutkan kembali kejayaan negeri Sambas sejak pemerintahan para Sultan Sambas dari tahun 1631-1943 M. Keinginan rakyat Sambas menjadikan kota Sambas sebagai ibukota Kabupaten Sambas terwujud sejak tanggal 15 Juli 1999. Pemerintahan Kabupaten Sambas berkedudukan di kota Sambas.

Islam di Kesultanan Sambas berkembang pesat pada masa pemerintahan Sultan Muhammad Syafiuddin II (1866-1922 M). Pada masa ini, Islam dikatakan benar-benar kokoh masuk ke dalam sendi-sendi pemerintahan. Masa kepemimpinan Sultan Muhammad Syafiuddin II dalam kenangan masyarakat disebut sebagai masa keemasan Kesultanan Sambas dengan julukan "Serambi Mekkah"4, gelar ini antara lain diberikan

\footnotetext{
${ }^{2}$ Uka Tjandrasasmita, Sejarah Nasional Indonesia (jilid 3) (Jakarta: Depdikbud, 1982), h. 80.

${ }^{3}$ Ansar Rahman dkk, Kabupaten Sambas: Sejarah Kesultanan dan Pemerintah Daerah (Sambas: Dinas Pariwisata PEMDA Kabupaten Sambas, 2001), h. 7.

${ }^{4}$ Dinamakan "Serambi Mekkah", berkaitan erat dengan banyaknya jumlah ulama Sambas yang pernah belajar di Mekkah dan Mesir. Ada beberapa faktor di juluki "Serambi Mekkah" di antaranya; kesejahteraan dan kemakmuran sosial ekonomi kesultanan, semangat keilmuan di bidang agama yang langsung dipelopori oleh sultan dan ulama, jaringan politik dan sosial yang kuat dengan kerajaankerajaan lain dan modernisasi yang dibawa dan diperkenalkan oleh Belanda. Lihat Pabali H. Musa,
} 
karena di kawasan ini lahir ulama besar berkaliber internasional yakni Ahmad Khatib Sambas (pendiri tarekat Qadiriyah wa Naqsabandiyyah), Muhammad Basiuni Imran, ia pernah cukup lama belajar di Mekkah dan sepulangnya ke Nusantara memainkan peran penting dalam menggulirkan wacana reformisme Islam. Kedua tokoh ini membawa Sambas mencapai puncak kebesarannya pada awal abad ke-20. Kemudian ditandai dengan kemajuan dalam lembaga keislaman seperti lembaga pendidikan Islam dan lembaga keagamaan, ${ }^{5}$ sebagaimana dalam QS Yüsuf/12: 111.

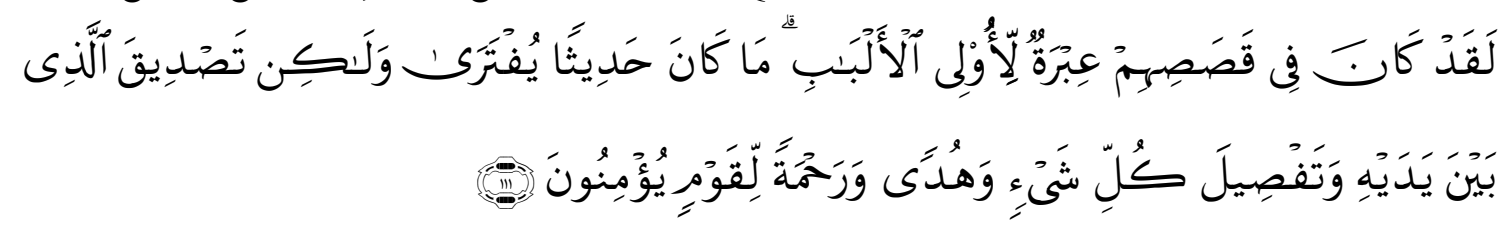

Terjemahnya:

"Sungguh, pada kisah-kisah mereka itu terdapat pengajaran bagi orang-orang yang mempunyai akal". (Al-Qur'an) itu bukanlah cerita yang dibuat-buat, tetapi membenarkan (kitab-kitab) yang sebelumnya, menjelaskan segala sesuatu, dan (sebagai) petunjuk dan rahmat bagi orang-orang yang beriman". 6

Pada ayat tersebut, Allah swt menegaskan pentingnya mempelajari dan memahami qisah atau sejarah, yakni agar manusia dengan akalnya dapat mengambil 'ibrah (pelajaran mendalam).

Selanjutnya, setelah Sultan Muhammad Syafiuddin II meninggal dunia, maka anaknya yang bernama Raden Muhammad Mulia Ibrahim diangkat menjadi sultan dengan gelar Sultan Muhammad Mulia Ibrahim Syafiuddin. Masa pemerintahan Sultan Muhammad Mulia Ibrahim Syafiuddin telah melakukan berbagai upaya untuk memajukan agama Islam di dalam maupun di luar kota Sambas sampai ke pelosok kampung. Kemudian ia mendirikan masjid Jami' atau masjid Agung di dalam kota, diikuti oleh rakyat dengan mendirikan masjid-masjid atau surau-surau dan madrasah di seluruh kampung.

Pemberantasan buta huruf Arab Jawi dan huruf Latin (bidang pendidikan Islam), menyebarluaskan pengertian seluk-beluk agama Islam, menghidupkan atau menguatkan hukum-hukum agama Islam dan hukum adat serta pranata sosial keagamaan, semua ini merupakan usaha Sultan Muhammad Mulia Ibrahim Syafiuddin dalam pengembangan agama Islam dan pelestarian adat. ${ }^{7}$ Sultan Muhammad Mulia Ibrahim Syafiuddin merenovasi kembali istana Sambas tanpa mengubah bentuk bangunan asli peninggalan masa Sultan Muhammad Syafiuddin II (1866-1922 M). Tujuan merenovasi istana Sambas oleh Sultan Muhammad Mulia Ibrahim Syafiuddin ialah untuk mengingat kembali akan peran dan pengaruhnya di Kesultanan Sambas dalam pengembangan Islam.

Pengaruh pemerintahan Sultan Muhammad Mulia Ibrahim Syafiuddin tidak hanya bergerak dalam bidang pendidikan, tetapi juga bergerak di bidang sosial-politik

Sejarah Kesultanan Sambas Kalimantan Barat: Kajian Naskah Asal Raja-Raja dan Silsilah Raja Sambas (Pontianak: STAIN Pontianak Press, 2003), h. 7.

${ }^{5}$ Erwin Mahrus, Rosadi Jamani dan Edy Kusnan Hadi, Shayk Ahmad Khatib Sambas: Sufi dan Ulama Besar Dikenal Dunia (1803-1875) (Pontianak: UNTAN Press, 2003), h. 10.

248.

${ }^{6}$ Kementerian Agama RI, Al-Qur'an dan Terjemahnya (Bandung: Semesta Al-Qur'an, 2013), h.

${ }^{7}$ Lisyawati Nurcahyani dkk, Sejarah Kerajaan Sambas (Pontianak: Direktorat Sejarah dan Nilai Tradisional, Proyek Inventarisasi dan Dokumentasi Sejarah Nasional, 1995), h. 34-35. 
menentang hegemoni kekuasaan fasisme Jepang. Sedang zaman kolonial Belanda, tepatnya pada tanggal 1 Mei 1931, Belanda mengikat kontrak politik dengan Sultan Muhammad Mulia Ibrahim Syafiudin, bahwa penyelenggaraan pemerintahan Kerajaan Sambas harus menyesuaikan diri dengan ketentuan yang termaktub dalam Staatsblad Pemerintah Hindia Belanda yang disebut dengan Korte Verklaring atau Akte Van Vereband.

Kekuasaan sultan menjadi terbatas, hanya merupakan daerah otonom yang berbentuk landschap. ${ }^{8}$ Dengan menguasai kerajaan ini penjajah Belanda berkepentingan untuk mengendalikannya dalam bentuk membuat suatu tata administratif sendiri terhadap sebagian besar kehidupan pusat kerajaan. Bentuk tata pemerintahan yang dibuat oleh Belanda tidak lain adalah Residen. Akibatnya, ibu kota Kerajaan Sambas memiliki tata administratif tersendiri yang dibuat oleh penguasa asing disamping sistem administrasi kerajaan. Dengan adanya dua sistem administrasi ini, Sambas tidak saja berfungsi sebagai pusat kerajaan melainkan juga sebagai ibukota pemerintahan, berada di bawah kolonial Belanda yang disebut dengan Residen Sambas. ${ }^{9}$

Kepada sultan sebagai Het Zelfbestuur dikuasakan oleh pemerintah Hindia Belanda antara lain untuk melaksanakan hukum agama Islam dan hukum adat. Sejak tahun 1936 dibentuk lembaga Peradilan Khusus untuk golongan pribumi di Sambas, melengkapi pengadilan agama yang sudah berlaku turun temurun dengan merujuk kepada hukum qisas menurut ajaran Islam. Pengadilan Negeri yang sebelumnya disebut Landraad untuk golongan pribumi diganti namanya dengan Pengadilan Balai Kanon yang diketuai oleh sultan dan sekaligus hakim tunggalnya, dibantu oleh seorang panitera, dua orang penasehat masing-masing dari pejabat Belanda dan pemuka agama Islam (Maharaja Imam). Penuntut umumnya adalah mantri polisi. Pengadilan setempat yang sebelumnya disebut Magistraat untuk golongan pribumi diganti dengan Pengadilan Balai Raja. Ketuanya adalah Kepala Distrik (Demang) sekaligus sebagai hakim tunggal. Paniteranya adalah juru tulis Kepala Distrik. Pengadilan Adat diganti namanya dengan Pengadilan Balai Bidai. Ketuanya adalah Ketua Adat, Kepala Benua atau Kepala Kampung. Anggotanya pemuka kampung seperti Lebai dan Penghulu. ${ }^{10}$

Sedangkan sosial keagamaan lebih difokuskan pada fenomena keagamaan masyarakat yang beragama Islam. Aktivitas keagamaan lebih berkembang di ibu kota, namun bukan berarti aktivitas keagamaan di luar ibu kota tidak berkembang. Karena itu untuk mengatur segala permasalahan keagamaan dari ibu kota sampai ke desa-desa sultan telah mendirikan lembaga keagamaan yang di pimpin oleh Maharaja Imam. Posisi Maharaja Imam dan para ulama atau haji menempati posisi yang tinggi dalam masyarakat kesultanan. Hal tersebut salah satunya tidak dapat dilepaskan bagaimana masyarakat memandang haji itu sendiri. Pentingnya posisi haji dapat dilihat dari penghargaan yang tinggi pada mereka, yang dalam setiap perhelatan para haji ditempatkan paling depan bersama para pejabat pemerintahan. Hal ini dikarenakan

\footnotetext{
${ }^{8}$ Landschap yaitu sultan masih memiliki wewenang untuk mengatur adat-istiadat, tanah, budaya, agama dan segala urusan pribumi, namun dalam pelaksanaannya tetap berada di bawah pengawasan pemerintah kolonial. Musni Umberan dkk, Sejarah Kerajaan Sambas (Pontianak: Depdikbud, 1995), h. 10.

${ }^{9}$ Lihat Pabali H. Musa, Sejarah Kesultanan Sambas Kalimantan Barat: Kajian Naskah Asal Raja-Raja dan Silsilah Raja Sambas, h. 75.

${ }^{10}$ Ansar Rahman dkk, Kabupaten Sambas, Sejarah Kesultanan Sambas dan Pemerintahan Daerah, h. 78 i.
} 
orang-orang yang bergelar haji ditempatkan paling depan bersama para pejabat pemerintahan. Hal ini dikarenakan orang-orang yang bergelar haji pada masa lalu tidak hanya berkaitan dengan kemampuan ekonomi, tetapi juga dihubungkan dengan tingkat penguasaan ilmu agama yang relatif lebih tinggi. ${ }^{11}$ Pada masa pemerintahan Sultan Muhammad Syafiuddin II sudah ada beberapa nama yang bergelar haji di antaranya seperti H. Muhammad Arif, H. Muhammad Imran, H. Muhammad Djabir, H. Muhammad Shaleh, H. Ahmad Fauzi, H. Muhammad Zainuddin dan masih banyak haji-haji yang belum diketahui nama-namanya. ${ }^{12}$

Informasi tentang jumlah orang-orang yang naik haji menerangkan bahwa pembinaan keagamaan masyarakat Kesultanan Sambas mengalami peningkatan dengan banyaknya jumlah jemaah haji karena setelah pulang haji, mereka adalah orang-orang yang aktif melakukan pengajaran dan pembinaan keagamaan di wilayahnya. Pengajaran dan pembinaan tersebut dilakukan di beberapa tempat misalnya di masjidmasjid, di lingkungan istana maupun di rumah-rumah guru mengaji. Terkait dengan aktivitas keagamaan di masjid setidaknya dapat diketahui dari laporan kolonial Belanda yang menyebutkan bahwa pada 1869 M banyak masjid di kesultanan yang menjadi pusat pengajaran dan tempat ibadah masyarakat Islam. ${ }^{13}$

\section{KAJIAN TEORETIS}

\section{A. Konsep Peran}

Peran sebagaimana yang dikemukakan oleh Peter Burke ${ }^{14}$ adalah pola-pola atau norma-norma perilaku yang diharapkan dari orang lain yang menduduki suatu posisi tertentu dalam struktur sosial. Menurut Soerjono Soekanto, peran merupakan aspek dinamis kedudukan (status), apabila seseorang melaksanakan hak dan kewajibannya sesuai dengan kedudukannya maka ia menjalankan suatu peranan. ${ }^{15}$ Sedangkan menurut Nurani Soyomukti peranan disebut sebagai aspek dinamis kedudukan (status), karena diantara keduanya saling berkaitan. ${ }^{16}$ Pengertian lain yang menyangkut tentang peran terdapat dalam karya Hugo F. Reading ${ }^{17}$ yang dikumpulkannya dari beberapa sosiolog, yang mengungkap makna peran di antaranya:

1. Bagian peran yang dimainkan seseorang

2. Cara-cara yang dilakukan untuk bertingkah laku sesuai suatu jabatan

3. Kewajiban-kewajiban yang melekat pada suatu posisi

\footnotetext{
${ }^{11}$ Syafaruddin Usman, Sambas Merajut Kisah Menenun Sejarah (Pontianak: tt, 2011), h. 89.

${ }^{12}$ Erwin Mahrus, Falsafah dan Gerakan Pendidikan Islam, Maharaja Imam Sambas Muhammad Basiuni Imran (1885-1976) (Pontianak: STAIN Pontianak Press, 2007), h. 29-30. ANRI, Borneo West no. $74,1869$.

${ }^{13}$ Husni Rahim, Sistem Otoritas dan Administrasi Islam: Studi tentang Pejabat Agama Masa Kesultanan dan Kolonial di Palembang (Jakarta: Logos, 1998), h. 52.

${ }^{14}$ Peter Burke, History and Social Theory diterjemahkan oleh Mestika Zed dan Zulfahmi dengan judul Sejarah dan Teori Sosial (Jakarta: Yayasan Obor Indonesia, 2001), h. 68.

${ }^{15}$ Soerjono Soekanto, Teori Peranan (Jakarta: Bumi Aksara, 2002), h. 243.

${ }^{16}$ Nurani Soyomukti, Pengantar Sosiologi: Dasar Analisis, Teori dan Pendekatan Menuju Analisis Masalah-Masalah Sosial, Perubahan Sosial dan Kajian-Kajian Strategis (Yogyakarta: Ar-Ruzz Media, 2010), h. 384. Untuk mengetahui tentang peran baca juga buku Achlis, Studi Perilaku dan Lingkungan Sosial Manusia (Bandung: Koperasi Mahasiswa Sekolah Tinggi Kesejahteraan Sosial, 1993), h. 114.

${ }^{17}$ Hugo F. Reading, Social Sciences-Dictionaries penerjemah Sahat Simamora dengan judul Kamus Ilmu-Ilmu Sosial (Cet. I; Jakarta: Rajawali, 1986), h. 360.
} 
4. Sikap, nilai dan tingkah laku yang ditentukan terhadap hak-hak yang melekat pada suatu status

5. Hal-hal unik yang diperlihatkan seseorang dalam melaksanakan syarat-syarat dari status tertentu.

Berdasarkan pengertian yang dikemukakan tersebut, maka dapat diketahui bahwa peranan merupakan aspek dinamis dari kedudukan, yaitu seseorang yang melaksanakan hak-hak dan kewajibannya sesuai dengan kedudukannya. Maka dikatakan seseorang telah menjalankan suatu peranan. Bila dipadukan pengertian peranan tersebut, maka seseorang dikatakan menjalankan peranan paling tidak mencakup tiga hal sebagai berikut:

1. Peranan meliputi norma-norma yang dihubungkan dengan posisi atau tempat seseorang dalam masyarakat

2. Peranan merupakan suatu konsep perihal apa yang dapat dilakukan oleh individu dalam masyarakat sebagai organisasi

3. Peranan juga dapat dikatakan sebagai perilaku individu yang penting bagi stuktur sosial.

Hakikatnya, peran juga dapat dirumuskan sebagai suatu rangkaian perilaku tertentu yang ditimbulkan oleh suatu jabatan tertentu. Kepribadian seseorang juga memengaruhi bagaimana peran itu harus dijalankan. Peran yang dimainkan hakikatnya tidak ada perbedaan, baik yang dimainkan atau diperankan pimpinan tingkat atas, menengah maupun bawah akan mempunyai peran yang sama.

Begitupun dengan peran sosial adalah pelaksanaan hak dan kewajiban seseorang sesuai dengan status sosialnya. Antara peran dan status sudah tidak dapat dipisahkan lagi. Tidak ada peran tanpa status sosial atau sebaliknya. Peran sosial bersifat dinamis sedangkan status sosial bersifat statis. Dalam masyarakat, peran dianggap sangat penting karena peran mengatur perilaku seseorang berdasarkan norma-norma yang berlaku di masyarakat. Dengan demikian, pola peran sama dengan pola perilaku.

Pola peran dalam masyarakat dapat dibedakan menjadi tiga macam, yaitu; Pertama, peran ideal, yaitu peran yang diharapkan masyarakat terhadap status-status tertentu. Kedua, peran yang diinginkan yaitu peran yang dianggap oleh diri sendiri. Ketiga, peran yang dikerjakan yaitu peran yang dilakukan individu sesuai dengan kenyataannya. ${ }^{18}$ Dari ketiga pola peran yang tepat dalam penelitian ini menggunakan pola peran yang pertama yaitu peran ideal sebab peran ideal ini sesuai dengan tokoh yang diteliti terkait sosok Sultan Muhammad Mulia Ibrahim Syafiuddin yang pandai, gigih dan memiliki jiwa patriotisme yang tinggi dalam menentang hegemoni kekuasaan fasisme Jepang, serta perannya dalam revitalisasi peradilan agama di Kesultanan Sambas.

\section{B. Revitalisasi Lembaga Peradilan Agama}

\section{Pengertian Revitalisasi}

Revitalisasi mengandung pengertian mengembalikan agar lembaga peradilan hidup dan berfungsi kembali. ${ }^{19}$ Upaya revitalisasi pengadilan dimaksudkan sebagai usaha untuk mengembalikan pengadilan menjadi lembaga yang bermakna, lembaga yang kembali kepada fungsi yang sesungguhnya dan lembaga yang penting bagi

\footnotetext{
${ }^{18}$ Soerjono Soekanto, Sosiologi Suatu Pengantar (Jakarta: PT. Raja Grafindo Persada, 1995), h. 126.

${ }^{19}$ Rusli Muhammad, "Rekonstruksi Lembaga Pengadilan Menuju Indonesia Baru”, UNISIA, no. 53 (2004): h. 250.
} 
kehidupan masyarakat. Rusli Muhammad mengungkapkan upaya revitalisasi dalam rangka rekonstruksi lembaga pengadilan dapat dilakukan dengan cara: ${ }^{20}$

Pertama, peningkatan kualitas teoritik. Usaha ini memfokuskan perhatian kepada kualitas teoritik personil yang harus dimiliki oleh jajaran penegak hukum. Untuk meningkatkan kualitas dari penegak hukum itu perlu diupayakan agar jenjang pendidikan yang selama ini hanya terbatas pada tingkat sarjana (S1) lebih ditingkatkan lagi dengan mengikuti pendidikan pada jenjang yang lebih tinggi S2 atau S3. Kemampuan berpikir teoritis hanya dapat diperoleh melalui jenjang pendidikan yang lebih tinggi.

Kedua, peningkatan kesadaran peran dan tanggung jawab. Dalam upaya revitalisasi pengadilan, maka posisi pengadilan yang telah terpinggirkan hendaknya dikembalikan ke posisi sentral. Untuk mengembalikan posisi tersebut, hanya dapat dicapai jika para hakim sebagai komponen pokok pengadilan lebih meningkatkan kesadaran akan peran dan tanggung jawabnya. Para hakim harus sungguh menyadari tentang peranan-peranan baik yang bersifat yuridis formal maupun yang bersifat yuridis materil.

Ketiga, perbaikan moral komponen pengadilan (hakim). Timbulnya kesadaran akan adanya tanggung jawab sangat tergantung kepada baik buruknya moral (akhlak) yang dimilikinya. Ketika moralnya baik, maka kesadaran terhadap tanggung jawab akan baik pula, sebaliknya jika moral buruk akan berakibat pula rendahnya kesadaran tanggung jawab. Oleh karena itu, untuk menyadarkan tumbuhnya kesadaran akan tanggung jawab, maka persoalan moral perlu mendapat perhatian.

Langkah perbaikan moralitas komponen pengadilan sudah saatnya harus dilakukan dan digalakkan mengingat moral para penegak hukum pada umumnya dapat dikatakan berada pada titik terendah, dan inilah salah satu faktor yang memengaruhi rendahnya kinerja lembaga pengadilan sehingga sulit menjalankan keseluruhan peranperan yang dimilikinya. Maka upaya revitalisasi pengadilan harus pula dilakukan dengan sasaran tumbuhnya kembali kesadaran akan peran dan tanggung jawab serta terjadinya perbaikan moralitas khususnya para hakim. ${ }^{21}$

2. Pengertian Lembaga dan Peradilan

Menurut KBBI, lembaga yaitu badan atau organisasi yang tugasnya mengadakan penelitian atas pengembangan ilmu. Definisi lain dari lembaga adalah pranata. Koentjaraningrat, lebih menyukai sebutan pranata dan mengelompokannya ke dalam delapan golongan dengan prinsip penggolongan berdasarkan kebutuhan hidup manusia. ${ }^{22}$ Sedangkan kata peradilan berasal dari kata "adil" dengan awalan "per" dengan imbuhan "an". Kata peradilan sebagai terjemahan dari "qadha", yang berarti memutuskan, melaksanakan, menyelesaikan. ${ }^{23}$ Dan adapula yang menyatakan bahwa umumnya kamus tidak membedakan antara peradilan dengan pengadilan. ${ }^{24}$ Dalam literatur fikih Islam, peradilan disebut "qadha" artinya "menyelesaikan", sebagaimana

\footnotetext{
${ }^{20}$ Rusli Muhammad, "Rekonstruksi Lembaga Pengadilan Menuju Indonesia Baru”, h. 251.

${ }^{21}$ Rusli Muhammad, "Rekonstruksi Lembaga Pengadilan Menuju Indonesia Baru", h. 252.

${ }^{22}$ Koentjaraningrat, Kebudayaan, Mentalitas dan Pembangunan (Jakarta: PT Gramedia Pustaka Utama, 1994), h. 16.

${ }^{23}$ Ahmad Warson Munawwir, Kamus Al-Munawwir Indonesia-Arab Terlengkap (Surabaya: Pustaka Progressif, 2007), h. 125.

${ }^{24}$ Tim Penyusun Kamus Pusat Pembinaan dan Pengembangan Bahasa, Kamus Besar Bahasa Indonesia (Cet. VII; Jakarta: Balai Pustaka, 1996), h. 7.
} 
QS Al-'Ah̆āàb33: 37. Ada juga yang berarti "menunaikan" sebagaimana QS AlJumu'ah 62/10.

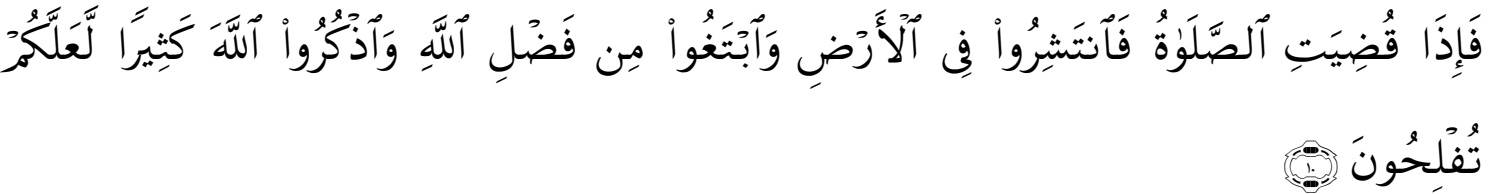

Terjemahnya:

"Apabila telah ditunaikan salat, maka bertebaranlah kamu di muka bumi; dan carilah karunia Allah dan ingatlah Allah banyak-banyak supaya kamu beruntung". 25

Di samping arti "menyelesaikan dan menunaikan". Arti qadha yang dimaksud ada juga yang berarti "memutuskan hukum", atau "menetapkan sesuatu ketetapan". Dalam dunia peradilan menurut para ahli, makna yang terakhir inilah yang dianggap lebih signifikan. Di mana makna suatu hukum di sini yaitu pada asalnya berarti "menghalangi" atau "mencegah", oleh karena itu qadhi dinamakan hakim karenanya seorang hakim berfungsi untuk menghalangi orang yang zalim dari penganiayaan. Oleh karena itu apabila seseorang mengatakan "hakim telah menghukumkan ataupun memutuskan begini" artinya hakim telah meletakkan sesuatu hak atau mengembalikan sesuatu kepada pemiliknya yang berhak. ${ }^{26}$ Secara terminologi, peradilan adalah suatu lembaga pemerintah atau negara yang ditugaskan untuk menyelesaikan atau menetapkan keputusan perkara dengan adil berdasarkan hukum yang berlaku. Jadi lembaga peradilan adalah suatu badan atau organisasi yang tugasnya memutuskan suatu masalah dan melakukan penelitian tentangnya.

Peradilan agama adalah salah satu lembaga pelaksana kekuasaan kehakiman yang harus menempatkan dirinya sebagai lembaga peradilan yang sesungguhnya yang disegani dan dihormati serta memiliki otoritas dan kewenangan yang tinggi. Peradilan agama sendiri adalah terjemahan dari bahasa Belanda yaitu godsdienstige rechtspraak. Kata godsdienstige berarti ibadah atau agama, adapun kata rechtspraak berarti peradilan. Dalam perundang-undangan Belanda istilah godsdienstige rechtspraak dipakai sebagai pemisah dari peradilan agama ke peradilan umum yang lebih bersifat keduniawian atau dikenal dengan istilah wereldlijke rechtpraak. ${ }^{27}$ Keberadaan $^{2}$ peradilan agama sendiri telah diakui jauh sebelum Negara Republik Indonesia ini memproklamirkan diri sebagai bangsa yang merdeka, meskipun sempat mengalami masa-masa pasang surut baik itu dari segi penamaan, status, kedudukan maupun kewenangannya.

3. Fungsi Peradilan

Sebagai lembaga negara mempunyai tugas untuk memutuskan setiap perkara dengan adil, maka peradilan harus memainkan fungsinya dengan baik. Diantara fungsi terpenting peradilan adalah: ${ }^{28}$

\footnotetext{
${ }^{25}$ Kementerian Agama RI, Al-Qur'an dan Terjemahnya (Bandung: Semesta Al-Qur'an, 2013), h. 423.

${ }^{26}$ Anonim, Pengertian Peradilan dalam Perspektif Hukum Islam, http://Www.informasiahli.com, diakses pada tanggal 19 Maret 2018, pukul 20.38 wita.

${ }^{27}$ Zaini Ahmad Noeh dan Abdul Basit Adnan, Sejarah Singkat Pengadilan Agama Islam di Indonesia (Surabaya: Bina Ilmu, 1980), h. 15.

${ }^{28}$ Anonim, Pengertian Peradilan dalam Perspektif Hukum Islam, http://Www.informasiahli.com, diakses pada tanggal 19 Maret 2018, pukul 20.38 wita.
} 
a. Menciptakan ketertiban dan ketentraman masyarakat

b. Mewujudkan keadilan yang menyeluruh bagi seluruh lapisan masyarakat

c. Melindungi jiwa, harta dan kehormatan masyarakat

d. Mengaplikasikan nilai-nilai amar makruf nahi munkar dengan menyampaikan hak kepada siapapun yang berhak menerimanya dan menghalangi orang-orang zalim dari tindak aniaya yang akan mereka lakukan.

4. Perkembangan Pembentukan Peradilan

Peradilan agama di Indonesia merupakan salah satu lembaga yang sangat tua, sehingga dalam sejarahnya yang panjang, peradilan mengalami berbagai pasang surut. Menurut Cik Hasan Bisri ${ }^{29}$, pada mulanya ia diorganisasikan secara sederhana, kemudian menjadi salah satu pelaksana kekuasaan pemerintah dalam bentuk dan wewenang yang beraneka ragam. Ia mengalami perkembangan yang pesat dalam struktur, kekuasaan, dan prosedurnya. Posisinya pun semakin penting, terutama dalam menjalankan fungsinya untuk menegakkan hukum dan keadilan. Pada masa kesultanan ini atau bisa juga dengan sebutan masa pra pemerintahan Hindia Belanda, sebagaimana perkembangannya terdapat tiga periode pembentukan peradilan, yakni sebagai berikut:

a) Tahkim kepada Muhakam

Pada awal periode masuknya Islam, bentuk peradilan yang dilaksanakan masih sangat sederhana. Yaitu dalam bentuk tahkim $^{30}$ kepada pemuka agama. Para pihak yang terlibat dalam suatu perkara perselisihan dengan sukarela menyerahkan perkara mereka kepada orang yang dianggap bisa menjadi penengah dan orang yang berperkara akan tunduk dengan keputusannya. Biasanya kepada guru atau mubalig yang dianggap mampu dan berilmu agama. Orang yang bertindak sebagai hakim di sebut muhakam Tradisi ini merupakan cikal bakal peradilan agama di Indonesia. ${ }^{31}$

b) Ahlul Halli Wal 'Aqdi

Peradilan atau qadla hukumnya fardhu kifayah dan dapat dilaksanakan dalam keadaan apapun juga. Dalam keadaan tidak ada qadli atau penguasa yang bisa melaksanakan, peradilan dapat dilaksanakan dengan cara tahkim pada seorang muhakam, seperti tahkim seorang wanita kepada seseorang untuk bertindak sebagai wali ataupun penyerahkan dua belah pihak yang berselisih kepada pihak ketiga untuk memutuskan perkaranya. Dalam suatu kelompok masyarakat yang sudah teratur, jabatan hakim atau qadli dapat dilakukan secara pemilihan dan bai'at oleh ahlul halli wal 'aqdi yakni pengangkatan atas seseorang yang dipercaya oleh majelis atau kumpulan orang-orang terkemuka dalam masyarakat. ${ }^{32}$

c) Tauliyah

Ketika kelompok masyarakat Islam telah berkembang menjadi kerajaan Islam, pengangkatan jabatan hakim qadi dilakukan dengan pemberian tauliyah. Tauliyah

\footnotetext{
${ }^{29}$ Cik Hasan Bisri, Peradilan Agama di Indonesia (Cet. IV; Jakarta: PT Raja Grafindo Persada, 2003), h. 113.

${ }^{30}$ Tahkim di sini merupakan lembaga penyelesaian sengketa antara orang-orang Islam yang dilakukan oleh para ahli agama.

${ }^{31}$ Abdul Halim, Peradilan Agama dalam Politik Hukum di Indonesia (Jakarta: Raja Grafindo Persada, 2000), h. 35. Lihat juga Sulaikin Lubis, Hukum Acara Perdata Peradilan Agama di Indonesia (Jakarta: Kencana, 2006), h. 22.

${ }^{32}$ Sulaikin Lubis, Hukum Acara Perdata Peradilan Agama di Indonesia, h. 23.
} 
yakni pemberian atau pendelegasian kekuasaan dari penguasa. ${ }^{33}$ Pada masa itu terdapat bermacam-macam sebutan atau nama, antara lain sebagai berikut: ${ }^{34}$

1. Di Aceh dengan nama Mahkamah Syar'iyah Jeumpa

2. Di Sumatera Utara dengan nama Mahkamah Majelis Syara'

3. Di Sulawesi, Maluku dan Irian Jaya yang merupakan bekas wilayah kerajaan Islam lebih disukai istilah Hakim Syara'

4. Di Kalimantan khususnya Kalimantan Selatan, karena peran Syekh Arsyad AlBanjari, Kerapatan Qadi dan Qadi Besar

5. Di Sumbawa Hakim Syara', di Sumatera Barat nama Mahkamah Tuan Qadi atau Angku Kali

6. Di Bima (NTB) dengan nama Badan Hukum Syara',

7. Di Kerajaan Mataram dengan Pengadilan Surambi.

Seiring perkembangan Islam maka hakim yang melaksanakan peradilan di angkat oleh Sultan atau Imam atau Raja, sama seperti halnya di Kesultanan Sambas.

Peradilan Agama di Indonesia telah ada sejak Islam ada di bumi Indonesia pada abad ke-7 atau ke-8 Masehi, sesuai dengan tingkat dan bentuknya sebagaimana ditentukan hukum Islam. ${ }^{35}$ Dalam perkembangan selanjutnya, Islam sebagai sebuah agama dan hukum semakin mengakar dan dominan mewarnai hampir seluruh kehidupan bangsa ini. Kenyataan ini sudah mulai berlaku sejak Islam ditetapkan sebagai agama resmi di Kerajaan Demak sekitar abad lima belas. Kemudian para sultan di Indonesia, di antaranya sultan di Aceh, Pagaruyung, Bonjol, Pajang, Banjar, dan Pasai, memberlakukan Islam sebagai agama resmi dan hukum negara. Akhirnya, puncak dominasi Islam berlaku pada zaman Kerajaan Mataram di tangan Sultan Agung sekitar $1750 \mathrm{M}$ yang memberlakukan hukum Islam secara total, baik dalam perkara pidana maupun perdata. Jadi, di Indonesia hukum Islam pernah diterima dan dilaksanakan seluruhnya oleh masyarakat Islam. ${ }^{36}$

Pada masa itu berlaku teori Receptio in Complexu yaitu bahwa hukum Islam diterima (diserap) secara menyeluruh oleh umat Islam. Teori ini dipelopori oleh Carl Frederik Winter, Salomon Keyzen, dan LWC van den Berg, yang menyatakan bahwa hukum itu mengikuti agama yang dianut oleh seseorang. Belakangan teori ini didukung oleh teori Receptio Exit yang dipelopori oleh Hazairin yang mengatakan bahwa hukum adat dapat berlaku apabila tidak bertentangan dengan hukum Islam. Akan tetapi, Snouck Hurgronje kemudian membuat teori yang disebut teori Receptio yaitu bahwa hukum yang berlaku bagi orang Islam adalah hukum adat mereka masing-masing. Hukum Islam bisa berlaku bila sudah diresapi oleh hukum adat. Jadi, hukum adatlah yang menentukan ada-tidaknya hukum Islam. Teori ini dikemukakan oleh C. Snouck Hurgronjedan C. van Vollenhoven. ${ }^{37}$

Dalam keadaan semacam itu, dalam rangka mendukung politik "memecah belah" (devide et impera), Pemerintah Kolonial Belanda mengeluarkan staablaad 1882 nomor 152 yaitu dengan memisahkan pelaksanaan hukum Islam di Jawa dan Madura dengan daerah luar Jawa dan Madura yang masih diserahkan kepada peraturan-

\footnotetext{
${ }^{33}$ Zaini Ahmad Noeh dan Abdul Basit Adnan, Sejarah Singkat Peradilan Agama Islam di Indonesia (Surabaya: Bina Ilmu, 1983), h. 30.

${ }^{34}$ Sulaikin Lubis, Hukum Acara Perdata Peradilan Agama di Indonesia, h. 23.

${ }^{35}$ Hamka, Sejarah Umat Islam Jilid III (Jakarta: Bulan Bintang, 198), h. 35.

${ }^{36}$ Ahmad Rofiq, Hukum Islam di Indonesia (Cet. IV; Jakarta: PT Raja Grafindo Persada, 2000), h. 12 .

${ }^{37}$ Ahmad Rofiq, Hukum Islam di Indonesia, h. 13.
} 
peraturan Adat dan Swapraja. Sejak itu, bentuk peradilannya tidak lagi berbentuk tahkim seperti pada awal-awal pemelukan Islam, melainkan sudah meningkat ke bentuk peradilan (qadla). Maka, mulai dikenal beberapa istilah: Sidang Jum'at, Rapat Ulama, Rapat Agama, Mahkamah Syara', dan Soerambi, dan istilah-istilah itulah yang kita kenal sebagai Peradilan Agama sekarang ini. Pengangkatan pengambil putusan atau hakimnya pun sudah tidak lagi berdasarkan penunjukkan langsung oleh para pihak yang bersengketa dan pemilihan serta bai'at ahlul halli wal 'aqdi, melainkan sudah melalui pemberian kekuasaan (tauliyah) oleh pemerintah dan penguasa (ulil amri). Maka, mulailah dikenal adanya peraturan-peraturan adat dan Swapraja sebagai dasar keberadaannya. Istilah-istilah lain yang kita kenal dengan Kanjeng Penghulu, Penghulu, Tuanku Mufti, maupun Tuanku Qadi, disamping raja-raja dan bupati dahulu, merupakan penjelmaan dari watak dan kepribadian ketatanegaraan dari pelaksanaan syariat Islam di Indonesia. ${ }^{38}$

Eksistensi dari sebuah lembaga peradilan sangat dibutuhkan oleh masyarakat Indonesia, tidak terkecuali bagi kalangan pemeluk agama mayoritas di negara ini, yaitu kaum muslim. Perbandingan antara jumlah pemeluk agama Islam dengan agama lainnya sangatlah jauh, permasalahan yang semakin banyak dan kompleks menjadikan kaum muslim membutuhkan lembaga peradilan khusus bagi kaum muslim, yang mana lembaga peradilan tersebut khusus menangani permasalahan perdata kaum muslim dan berasaskan kepada Alquran dan Hadis.

Peradilan agama merupakan salah satu literatur resmi diantara lembaga peradilan atau kekuasaan kehakiman lainnya. Peradilan agama adalah salah satu peradilan khusus di Indonesia. Dua peradilan khusus lainnya adalah Peradilan Militer dan Peradilan Tata Usaha Negara. Dikatakan sebagai peradilan khusus karena peradilan agama mengadili perkara-perkara tertentu. Dalam hal ini wewenang peradilan agama hanya di bidang perdata saja dan tidak bisa menangani perkara di bidang pidana dan hanya berlaku bagi kalangan penganut agama Islam. ${ }^{39}$ Kemudian setelah lahirnya Undang-Undang No. 7 Tahun 1989 yang telah diubah dan ditambah dengan Undang-Undang No. 3 Tahun 2006. Pada perubahan kedua di ubah menjadi Undang-Undang No. 50 Tahun 2009 tentang Peradilan Agama. Dengan demikian, lahirnya undang-undang tersebut membuat beberapa perubahan yang signifikan bagi peradilan agama dan menjadikan kedudukannya semakin kuat dan betul-betul eksis. ${ }^{40}$

Hal itu ditandai dengan kewenangannya yang dapat mengeksekusi putusannya sendiri. Hal tersebut mengandung arti yang cukup luas, yang mana aparatur pengadilan agama yang meliputi para hakim, panitera dan juru sita dituntut untuk bekerja secara sigap dengan profesionalisme yang tinggi dalam menjalankan tugas-tugas dan wewenangnya agar tercipta sebuah lembaga peradilan yang bersih, jujur dan adil dalam memberikan sebuah putusan. Agar tercipta peradilan yang baik, adil dan cepat pengadilan agama harus meningkatkan kualitas semua jajaran aparatnya sehingga dalam melaksanakan tugas-tugasnya dapat melaksanakan dengan hukum acara yang baik dan benar, hal ini sesuai dengan ketentuan-ketentuan yang berlaku atau telah ditetapkan.

\footnotetext{
${ }^{38}$ Sumadi Matrais, "Kemandirian Peradilan Agama dalam Perspektif Undang-Undang Peradilan Agama", Hukum 15, no. 1 (2008): h. 124.

${ }^{39}$ A. Basiq Djalil, Peradilan Agama di Indonesia (Jakarta: Kencana, 2006), h. 9

${ }^{40}$ R. Wirjono Projodikoro, Hukum Acara Perdata di Indonesia (Bandung: Sumur Bandung, 1992), h. 8 .
} 
Sejarah peradilan agama di Indonesia telah ada sejak zaman kerajaan-kerajaan Islam, kemudian pada zaman kolonialisasi Belanda dan Jepang. Sesudah kemerdekaan sampai akhirnya keluar Undang-Undang No. 7 Tahun 1989 tentang Pengadilan Agama yang lebih mempertegas lagi kedudukan pengadilan agama di Indonesia. Proses interaksi peradilan agama ini telah berlangsung dalam jangka waktu yang panjang sejak masyarakat Islam memiliki kekuatan politik pada masa kesultanan Islam hingga sekarang, maka ketika disebutkan peradilan agama maka yang dimaksudkan adalah peradilan Islam di Indonesia.

Kelembagaan peradilan agama sebagai wadah dan hukum Islam sebagai muatan atau isi pokok pegangan dalam menyelesaikan dan memutus perkara, tidak dapat dipisahkan. Dalam sejarah perkembangannya, kelembagaan peradilan agama mengalami pasang surut. Pada masa kekuasaan kerajaan Islam lembaga peradilan agama termasuk bagian yang tidak terpisahkan dengan pemerintahan umum, sebagai penghulu keraton yang mengurus keagamaan Islam dalam semua aspek kehidupan. Pada masa pemerintahan VOC, kelembagaan peradilan agama akan dihapuskan dengan membentuk peradilan tersendiri dengan hukum yang berlaku di negeri Belanda, namun kelembagaan ini tidak dapat berjalan karena tidak menerapkan hukum Islam. ${ }^{41}$

Di zaman pemerintahan Hindia Belanda, peradilan agama berkembang di daerah-daerah dalam keadaan tidak sama, baik namanya, wewenangnya, maupun strukturnya. Ada beberapa sebutan nama peradilan agama pada waktu itu seperti Rapat Ulama, Raad Agama, Priessteraa, Peradilan Paderi, Godsdientige Rechtspark, Godsdientst Beatme, Hof Voor Islamietische Zaaken, Kerapatan Qadi Besar dan sebagainya. ${ }^{42}$ Pemerintah kolonial Belanda untuk pertama kali dibentuk peradilan agama yang berbeda-beda dalam wilayah Hindia-Belanda (Indonesia) seperti: ${ }^{43}$

1. Di Jawa dan Madura terdapat peradilan agama tetapi hakim tersendiri tidak ada, peradilan agama dilakukan oleh pemimpin-pemimpin masjid yang dinamakan penghulu.

2. Di Aceh, Jambi, Sambas, Pontianak, di daerah-daerah pantai Kalimantan Tenggara, Sulawesi, Ternate, Ambon terdapat hakim agama tersendiri, di samping pegawaipegawai masjid, hakim agama yang disebut Kali, Qadi atau Hakim.

3. Di Minangkabau atau Sumatera Barat sekarang tidak terdapat hakim agama tersendiri akan tetapi urusan agama di adili oleh Rapat Agama Nagari yang anggota-anggotanya terdri dari kepala-kepala Nagari.

4. Di Tanah Gayo, Alas dan Batak di Sumatera, sebagian besar Sumatera Selatan, Bangka, Belitung dan Minahasa hanya dikenal segolongan pegawai agama yang diserahi memelihara masjid-masjid, pegawainya melaksanakan perkawinan dan pekerjaan lain-lain menurut syariat Islam, tetapi disamping itu tidak melakukan kekuasaan kehakiman. Oleh karena tidak adanya hakim agama maka sengketa tentang perkawinan dan perceraian diselesaikan diantara hakim pribumi.

Begitupun yang ada di Sambas, sebutan nama peradilan agama khusus untuk pribumi masa kolonialisasi Belanda berbeda dengan daerah-daerah yang lain. Masa

\footnotetext{
${ }^{41}$ Endah P, Sejarah Peradilan Agama, https://badilag.mahkamahagung.go.id di akses pada tanggal 24 Maret 2018, pukul 19.58 wita.

${ }^{42}$ Muhammad Sukri, Sejarah Peradilan Agama di Indonesia (Pendekatan Yuridis), https://WWw.google.com-sejarah-peradilan-agama-di-indonesia.pdf, diakses pada tanggal 31 Januari 2019, pukul 13.15 wita.

${ }^{43}$ Asep Iman Suwargana, Sejarah Peradilan Agama di Indonesia dalam http://asepimansuwargana.blogspot.com di akses pada tanggal 31 Januari 2019, pukul 14.00 wita.
} 


\section{Peran Sultan Muhammad Mulia Ibrahim Syafiuddin di Kesultanan Sambas 1931-1943 ...}

Sultan Muhammad Mulia Ibrahim Syafiuddin memerintah di Kesultanan Sambas 19311943, merevitalisasi lembaga peradilan agama akan dipaparkan dalam hasil penelitian dan pembahasan selanjutnya.

Pengakuan akan adanya peradilan agama secara resmi sangatlah berarti bagi tumbuhnya salah satu institusi penegak keadilan di nusantara ini, meskipun dalam praktiknya pelaksanaan lembaga peradilan ini selalu di setir oleh pemerintah kolonial Belanda. Oleh karena itu, keberadaan peradilan agama seperti itu belum menjamin terlaksananya lembaga peradilan yang didasarkan pada nilai-nilai keislaman. Berbagai usaha telah dilakukan oleh umat Islam dalam rangka mewujudkan lembaga peradilan agama yang diimpikan. Usaha ini ternyata memakan waktu yang cukup lama. Setelah melalui berbagai tahapan, baru pada tahun 1989 yang khusus mengatur peradilan agama. Dengan keluarnya undang-undang ini maka keberadaan peradilan agama mempunyai landasan hukum yang formal (landasan yuridis formal) dan diakui sejajar dengan badan-badan peradilan lainnya yang sama-sama melaksanakan fungsi kehakiman di Indonesia. ${ }^{44}$

Secara yuridis, peradilan agama dimasukkan ke dalam lingkungan peradilan di Indonesia adalah bahwa Negara Republik Indonesia, sebagai negara hukum yang berdasarkan Pancasila dan Undang-Undang Dasar 1945, bertujuan mewujudkan tata kehidupan bangsa yang sejahtera, aman, tenteram, dan tertib. Pasal 27 ayat (1) Undang-Undang Dasar 1945 menyatakan: Segala warga Negara bersamaan kedudukannya di dalam hukum dan Pemerintahan dan wajib menjunjung Hukum dan Pemerintahan itu dengan tidak ada kecualinya. Sedangkan Pasal 29 ayat (1) dan (3) Undang-Undang Dasar 1945 juga menyatakan: (1) Negara berdasar atas Ke-Tuhanan Yang Maha Esa, (2) Negara menjamin kemerdekaan tiap-tiap penduduk untuk memeluk agamanya masing-masing dan untuk beribadat menurut agamanya dan kepercayaannya itu. $^{45}$

Selama pemerintahan Orde Baru, pembinaan dan pengawasan Peradilan Agama sebagai salah satu pelaksana Kekuasaan Kehakiman, sebagaimana lembaga peradilan lainnya, dilakukan oleh dua lembaga yakni Yudikatif dan Eksekutif. Pembinaan itu dilakukan oleh Mahkamah Agung, sedangkan pembinaan organisasi, administrasi, dan keuangan badan oleh Departemen Agama, berdasarkan Pasal 10 dan Pasal 11 ayat (1) Undang-Undang No. 14 Tahun 1970 tentang Ketentuan-Ketentuan Pokok Kekuasaan Kehakiman Pasal 5 Undang-Undang No. 7 Tahun 1989 tentang Peradilan Agama, di mana sekarang sudah diubah dengan Pasal 13 ayat (1) Undang-Undang No. 4 Tahun 2004.

Di masa pemerintahan Reformasi Pembangunan, pembinaan dan pengawasan yang dilakukan Yudikatif dan Eksekutif tersebut sudah dianggap tidak layak lagi, karena jelas mempengaruhi kemandirian Badan Peradilan Agama. Maka harus diadakan perubahan agar Eksekutif tidak mencampuri Yudikatif dan pada tanggal 30 Juli 1999 disahkan Undang-Undang No. 35 Tahun 1999 tentang Perubahan atas Undang-Undang No. 14 Tahun 1970 tentang Ketentuan-Ketentuan Pokok Kekuasaan Kehakiman. Sekarang undang-undang tersebut telah diubah menjadi Undang-Undang No. 4 Tahun 2004 tentang Kekuasaan Kehakiman. Pasal 13 ayat (1) Undang-Undang

\footnotetext{
${ }^{44}$ Marzuki, Peradilan Agama Sebagai Institusi Penegak Hukum Islam di Indonesia, http://staffnew.uny.ac.id/di akses pada tanggal 01 Februari 2019, pukul 13.18 wita.

${ }^{45}$ Sumadi Matrais, "Kemandirian Peradilan Agama dalam Perspektif Undang-Undang Peradilan Agama", h. 138.
} 
Nomor 4 Tahun 2004 tentang Kekuasaan Kehakiman berbunyi: organisasi, administrasi, dan finansial Mahkamah Agung dan badan peradilan yang berada di bawahnya, berada di bawah kekuasaan Mahkamah Agung. Disahkannya undangundang tersebut menjadi peristiwa yang sangat bersejarah bagi lembaga kekuasaan kehakiman, karena menjadi tonggak sejarah bagi terwujudnya kemerdekaan dan kemandirian dari kekuasaan kehakiman secara utuh di bawah Mahkamah Agung, setelah sekian lama pembinaan atasnya dilakukan oleh dua lembaga kekuasaan: Eksekutif (departemen yang bersangkutan) dan Yudikatif (Mahkamah Agung).

Tujuan pemisahan kekuasaan antara Eksekutif dan Yudikatif yang dikehendaki dan di atur oleh Undang-Undang Nomor 4 Tahun 2004 tentang Kekuasaan Kehakiman tersebut adalah memantapkan proses Lembaga Peradilan Agama dalam segi-segi hukum formal dan teknis peradilan, sehingga dapat terwujud Kekuasaan Kehakiman yang merdeka dengan terselenggaranya peradilan yang bebas dari pengaruh dan intervensi kekuasaan Eksekutif dan benar-benar mandiri. Namun, ternyata realisasi kehendak Undang-Undang tersebut bukan hal yang mudah, yang langsung bisa dilaksanakan dengan disahkannya Undang-Undang tersebut. ${ }^{46}$

Maka, untuk mewujudkan tata kehidupan seperti itu dan untuk menjamin kesederajatan kedudukan warga negara di dalam hukum diperlukan upaya menegakkan keadilan, kebenaran, ketertiban, dan kepastian hukum yang mampu memberikan pengayoman atas warga masyarakat. Dan salah satu upaya menegakkan keadilan, kebenaran, ketertiban, dan kepastian hukum tersebut adalah melalui Pengadilan Agama.

\section{METODOLOGI PENELITIAN}

Jenis penelitian ini adalah penelitian kualitatif. Berdasarkan letak lokasi penelitian yakni Kabupaten Sambas, maka literatur tertulis yang menjadi bahan rujukan dalam pembahasan ini adalah seluruh karya tulis yang membahas masyarakat Kalimantan Barat pada umumnya dan masyarakat Sambas pada khususnya sebagai fokus lokasi penelitian. Pendekatan dalam teori keilmuan yang akan digunakan dalam analisis pembahasan ini, selain pendekatan teori sejarah, yakni pendekatan teori sosiologi, antropologi, politik, teologi dan psikologi.

Sumber data, pencarian sumber disebut juga heuristik, merupakan proses yang dilakukan oleh peneliti sejarah untuk mengumpulkan sumber-sumber sejarah. Sumber Primer yang digunakan adalah arsip Silsilah Kesultanan Sambas no. 28, manuskrip Kisah Negeri Sambas 1568-1944, 10 Juli 1991, no. 31, manuskrip Silsilah Sultan Muhammad Syafiuddin (Sambas) tahun 1903, no. 40, ANRI, ANRI, Borneo West No.72, 1867, Borneo Simboen Pontianak, Tahun ke II, No. 135, 1 Juli 1944, peninggalan arkeologis berupa keraton (istana) dan masjid, wawancara dengan beberapa informan yang dianggap mengetahui tokoh yang diteliti di Kesultanan Sambas. Sedangkan Sumber Sekunder berupa; karya tulis ilmiah, berupa laporan hasil penelitian, disertasi, buku-buku, jurnal/artikel, newspapers, yang mempunyai relevansi dalam pembahasan ini. Hanya saja perlu diketahui, bahwa sebelum sumber-sumber sejarah itu digunakan, ia terlebih dahulu harus dikritik, baik secara intern maupun ekstern dan kemudian diinterpretasi. Hal ini dilakukan dengan tujuan agar kisah

\footnotetext{
${ }^{46}$ Sumadi Matrais, "Kemandirian Peradilan Agama dalam Perspektif Undang-Undang Peradilan Agama", h. 136.
} 
sejarah yang dihasilkan dapat bersifat ilmiah, artinya tidak bersifat spekulasi yang memungkinkan tergelincir pada mitologi.

Metode pengumpulan data menggunakan metode sejarah ada empat langkah penelitian yang digunakan yaitu heuristik, verifikasi, interpretasi dan historiografi. Instrumen penelitian, dalam penelitian kualitatif, yang menjadi instrumen atau alat penelitian adalah peneliti sendiri. Teknik Pengolahan dan Analisis Data pada sumbersumber data dilakukan dengan cara direduksi, dirangkum, dan disusun secara sistematis. Uji keabsahan data dalam penelitian ditekankan pada uji validitas dan reabilitas. Dalam penelitian kualitatif, data dapat dinyatakan valid apabila tidak ada perbedaan antara yang dilaporkan peneliti dengan realitas obyek yang diteliti. Hal utama dalam pengujian keabsahan data adalah uji autentisitas dan kredibilitas data. Oleh sebab itu, prinsip-prinsip dalam proses kritik data menjadi keniscayaan. Di saat bersamaan, peneliti sebagai instrumen utama dalam penelitian ini, dituntut sikap kejujuran dan obyektifitas sebagai bentuk konsekuensi prinsip ilmiah.

\section{HASIL PENELITIAN DAN PEMBAHASAN}

Sebelum pemerintah Hindia Belanda mengukuhkan kekuasaannya di Indonesia, tata hukum di Indonesia mendapatkan pengaruh dari hukum agama yaitu Hindu dan Islam serta hukum adat. Hukum Islam sebagai hukum yang berdiri sendiri sudah tumbuh dan berkembang dalam masyarakat berdampingan dengan kebiasaan-kebiasaan yang ada dalam masyarakat. Sebelum agama Islam masuk ke Indonesia, di zaman kerajaan Hindu sudah terdapat lembaga peradilan. Lembaga peradilan itu terbagi menjadi dua yaitu peradilan Perdata dan Padu. Yang termasuk perkara perdata pada umumnya perkara-perkara yang dapat membahayakan mahkota, keamanan, dan ketertiban negara, seperti membuat kerusuhan, pencurian, pembunuhan, perampokan dan lain sebagainya. Perkara ini di adili di peradilan perdata yang dilakukan sendiri oleh raja. Sementara itu perkara-perkara yang mengenai perseorangan diadili oleh pejabat negara yang disebut jaksa. Peradilan ini dilaksanakan di pengadilan Padu. ${ }^{47}$

Masuknya agama Islam ke Indonesia, maka tata hukum di Indonesia mengalami perubahan. Hukum Islam tidak hanya menggantikan hukum Hindu, yang berwujud dalam hukum perdata, tetapi juga memasukkan pengaruhnya ke dalam berbagai aspek kehidupan masyarakat pada umumnya. Meskipun, hukum asli masih menunjukkan keberadaannya, tetapi hukum Islam telah menyebar di kalangan para penganutnya terutama hukum keluarga. Hal itulah yang memengaruhi terhadap proses pembentukan dan pengembangan peradilan agama di Indonesia.

Pertumbuhan dan perkembangan peradilan agama pada masa kesultanan Islam bercorak majemuk. Kemajemukan itu sangat bergantung kepada proses islamisasi yang dilakukan oleh pejabat agama dan ulama bebas dari kalangan pesantren, dan bentuk integrasi antara hukum Islam dengan kaidah lokal yang hidup dan berkembang sebelumnya. Kemajemukan peradilan itu terletak pada otonomi dan perkembangannya, yang berada dalam lingkungan kesultanan masing-masing. Selain itu, terlihat dalam susunan pengadilan dan hierarkinya, kekuasaan pengadilan dalam kaitannya dengan

\footnotetext{
${ }^{47}$ Mengenai pemisahan di antara perkara perdata dan perkara padu ini tidak bersifat mutlak. Ada kalanya, bahwa suatu perkara yang biasanya termasuk perkara padu, di dalam keadaan tertentu menjadi berubah sifatnya, yaitu dianggap seperti perkara perdata, maka harus diadili oleh pengadilan raja. Lihat R. Tresna, Peradilan di Indonesia dari Abad ke Abad (Jakarta: Pradnya Paramita, 1978), h. 16.
} 
kekuasaan pemerintahan secara umum, dan sumber pengambilan hukum dalam penerimaan dan penyelesaian perkara yang diajukan kepadanya. ${ }^{48}$

Raden Muhammad Mulia Ibrahim adalah putra Pangeran Adipati Ahmad bin Sultan Muhammad Syafiuddin II dengan permaisurinya yang bernama Utin Putri binti Panembahan Muhammad Ibrahim Raja Mempawah. Baginda dilahirkan di Sambas, 18 September 1901 dan diangkat sebagai putra mahkota dengan gelar Pangeran Ratu Nata Wijaya menggantikan ayahndanya Pangeran Adipati Ahmad yang wafat pada tanggal 21 Agustus $1916 \mathrm{M}$ sebelum sempat menjadi sultan. Baginda diangkat menjadi sultan pada tanggal 2 Mei 1931 M dengan gelar Sultan Muhammad Mulia Ibrahim Syafiuddin, merupakan sultan Sambas ke-15. ${ }^{49}$ Para Sultan Sambas yang dimulai dari Sultan Muhammad Syafiuddin I sampai wafatnya Sultan Muhammad Mulia Ibrahim Syafiuddin, selama 312 tahun telah mengembangkan Islam. Selain mendirikan Istana Kesultanan, para sultan juga mendirikan masjid dan menganjurkan kepada masyarakat untuk membangun surau dan masjid di setiap perkampungan. ${ }^{50}$ Sebelum adanya campur tangan penjajah Belanda. Pengadilan agama di Kesultanan Sambas secara turun-temurun melaksanakan hukum Islam yang berpedoman pada Alquran dan Hadis Nabi yang juga menerapkan qisas menurut hukum Islam. Misalnya membunuh dihukum bunuh, berzina dikenakan hukum rajam.

Sejak tahun 1818 M Kolonial Belanda telah menduduki kawasan Sambas dan kantor perwakilannya di kawasan ini, telah membawa kesan negatif atas berbagai kebijakan politik keagamaan yang telah dilakukan, seperti usaha memisahkan antara hukum Islam yang merupakan bagian yang tidak terpisahkan daripada adat Melayu dan rujukan utama dalam seluruh aspek kehidupan dengan hukum adat. Sudah tentu, tujuan utamanya adalah untuk membawa Islam dalam sebuah rumusan yang sempit dan langkah strateginya bagi mengekalkan kekuasaan kolonial. Oleh sebab itu, pemerintah Belanda telah membuat beberapa kebijakan. Pertama, Islam hanya dalam bidang agama murni (ibadah). Kedua, bidang sosial kemasyarakatan pemerintah memanfaatkan hukum adat sebagai sebuah perundangan. Ketiga, bidang politik pemerintah harus mencegah setiap usaha yang akan membawa rakyat kepada fanatisme politik panIslam. $^{51}$

Usaha-usaha untuk menghapuskan peradilan agama yang identik dengan hukum Islam, sudah dimulai sejak VOC mulai menginjakkan kaki di bumi Nusantara. Usaha tersebut dengan cara mengurangi kewenangan peradilan agama sedikit demi sedikit. Pada tahun 1830 pemerintah Belanda menempatkan peradilan agama di bawah pengawasan “Landraad” (Pengadilan Negeri). Hanya lembaga Landraad yang berkuasa untuk memerintahkan pelaksanaan putusan pengadilan agama dalam bentuk "excecutoire verklaring" (pelaksanaan putusan). Pengadilan agama tidak berwenang untuk menyita barang dan uang. Dan tidak adanya kewenangan yang seperti ini terus

\footnotetext{
${ }^{48}$ Cik Hasan Bisri, Peradilan Agama di Indonesia, h. 113.

${ }^{49}$ Wawancara dengan Pangeran Ratu Muhammad Tarhan adalah cicit dari Sultan Muhammad Syafiuddin II dan cucu dari Sultan Muhammad Mulia Ibrahim Syafiuddin. (Raden Muhammad Tarhan bin Raden Ratu H. Winata Kesuma bin Ratu Muhammad Taufiq bin Sultan Muhammad Mulia Ibrahim Syafiuddin), pada tanggal 28 Maret 2018.

${ }^{50}$ K Subroto, "Negara-Negara Islam di Kalimantan 1425-1905 M”, (Laporan), Syamina, edisi 18 (Desember 2017), h. 23. Lihat juga arsip Silsilah Kesultanan Sambas no. 28, manuskrip Kisah Negeri Sambas 1568-1944, manuskrip Silsilah Sultan Muhammad Syafiuddin (Sambas) tahun 1903, no. 40.

${ }^{51}$ Didik M Nur Haris dan Rahimin Affandi Abd Rahim, "Pemikiran Keagamaan Muhammad Basiuni Imran", Al-Banjari 16, no. 2 (2017): h. 4.
} 
berlangsung sampai dengan lahirnya Undang-Undang Nomor 1 Tahun 1974 tentang perkawinan. Dengan lahirnya Undang-Undang Nomor 1 Tahun 1974 tentang perkawinan memperkokoh keberadaan pengadilan agama. Di dalam undang-undang ini tidak ada ketentuan yang bertentangan dengan ajaran Islam. Dalam pasal 2 ayat 1 dalam undang-undang ini semakin memperteguh pelaksanaan ajaran Islam (hukum Islam). ${ }^{52}$

Diakuinya peradilan untuk orang pribumi, yaitu peradilan adat dan peradilan desa karena Belanda menyadari bahwa mereka tidak bisa menyelesaikan sendiri seluruh persoalan yang dihadapi oleh penduduk Hindia Belanda sendiri dengan menggunakan peradilan Eropa. Pembagian penggolongan penduduk oleh Belanda dipandang sebagai solusi atas masalah tersebut, oleh sebabnya pasal 163 Indische Staatsregeling menegaskan golongan penduduk di Hindia Belanda di bagi menjadi tiga yaitu golongan penduduk Eropa, golongan penduduk Timur Asing dan golongan penduduk Pribumi. Tiap golongan penduduk tersebut menerapkan aturan hukum yang sesuai dengan golongan masing-masing apabila terjadi perkara, kecuali melakukan penundukan diri ke hukum yang digunakan oleh pemerintah Belanda. ${ }^{53}$

Tepatnya pada tanggal 1 Mei 1931, Belanda mengikat kontrak politik dengan Sultan Muhammad Mulia Ibrahim Syafiuddin, bahwa penyelenggaraan pemerintahan Kerajaan Sambas harus menyesuaikan diri dengan ketentuan yang termaktub dalam staatsblad. Pemerintah Hindia Belanda yang disebut dengan korte verklaring atau akte van vereband. Kekuasaan Sultan menjadi terbatas, hanya merupakan daerah otonom yang berbentuk lanschap. Kepada Sultan sebagai het zelfbestuur dikuasakan oleh pemerintah Hindia Belanda antara lain untuk melaksanakan hukum agama Islam dan hukum adat. Seperti saat di wawancarai U. Riza Fahmi menjelaskan: ${ }^{54}$

"Mase Sultan Muhammad Mulia Ibrahim Syafiuddin saat die bekuase sampat bentuk peradilan khusus untuk golongan pribumi tahun 1936. Walaupun sebelumnye jak udah ade juak name peradilan khusus ye cume di ganti namenye dianterenye landraad untuk menyebut pengadilan negeri digantinye jadi pengadilan balai kanon, magistraat untuk nyebut name pengadilan setempat untuk golongan pribumi digantinye jadi pengadilan balai raje, lakak iye pengadilan adat digantinye jadi pengadilan balai bidai."

Pada masa Sultan Muhammad Mulia Ibrahim Syafiuddin memerintah merevitalisasi peradilan khusus untuk golongan pribumi tahun 1936. Meskipun, sebelumnya pernah ada hanya namanya yang diganti dan pelaksanaan hukumnya berpedoman kepada hukum adat setempat di antaranya peradilan khusus untuk golongan pribumi, yaitu: ${ }^{55}$

${ }^{52}$ Syed Hussein Alatas, Sosiologi Korupsi Sebuah Penjelajahan dengan Data Kontemporer (Jakarta: LP3ES, 1986), h. 155.

${ }^{53}$ Herlambang P. Wiratraman, "Perkembangan Politik Hukum Peradilan Adat", Mimbar Hukum 30, no. 3 (2018): h. 493.

${ }^{54}$ Wawancara dengan Urai Riza Fahmi selaku cucu Sultan Muhammad Syafiuddin II bekerja di Dinas Komunikasi, Budaya dan Pariwisata Kabupaten Sambas sekaligus sebagai sekretaris Keraton Alwazikubillah Sambas, pada tanggal 27 Maret 2018.

${ }^{55}$ Bakran Suni dkk, Laporan Akhir Penelitian Sejarah Melayu Sambas (Pontianak: Lembaga Penelitian UNTAN dan Pemda Sambas, 2007), h. 40. 
1) Pengadilan Negeri yang sebelumnya disebut landraad untuk golongan pribumi diganti namanya dengan Pengadilan Balai Kanon

Pengadilan Balai Kanon dikuasai oleh Sultan Sambas sebagai hakim tunggal dibantu seorang panitera dan sebagai penasehatnya seorang pejabat pemerintah Belanda dan pemuka agama Islam (Maharaja Imam). Penuntut umumnya adalah Mantri Polisi dan hukuman yang dijatuhkan kepada tersangka berpedoman pada KUHP (Kitab Undang-Undang Hukum Pidana) dan peraturan-peraturan lainnya yang ancaman hukumannya diatas enam bulan. Keputusan pengadilan Balai Kanon harus diperkuat oleh pengadilan negeri atau landraad yang berkedudukan di Singkawang. Balai Kanon merupakan lembaga tertinggi di Kesultanan Sambas yang mengurusi masalah pidana/perdata mengenai soal hukuman tahanan, pusaka dan perkawinan.

2) Pengadilan Setempat yang sebelumnya disebut magistraat untuk golongan pribumi diganti dengan Pengadilan Balai Raja

Pengadilan Balai Raja sebagai ketua pengadilan ditunjuk kepala distrik (Demang) sebagai hakim tunggal. Paniteranya adalah juru tulis kepala distrik. Jaksa penunt ut umum ditunjuk Mantri Polisi setempat dan hukuman yang dijatuhkan kepada terdakwa berpedoman kepada KUHP dan peraturan-peraturan lainnya yang ancaman hukumannya dibawah enam bulan. Keputusan pengadilan Balai Raja harus diperkuat oleh kepala pemerintahan setempat (controleur). Balai Raja juga lembaga yang mengurusi masalah pidana/perdata, harta warisan dan perkawinan pada tahap yang lebih ringan, misalnya penetapan hukuman bagi kejahatan pidana/perdata mulai dari tiga bulan sampai tiga tahun.

3) Pengadilan Adat diganti namanya dengan Pengadilan Balai Bidai

Pengadilan Balai Bidai (pengadilan adat) dilaksanakan oleh Ketua Adat, Kepala Benua, Kepala Kampung sebagai Ketua Pengadilan Balai Bidai. Anggota dari pemuka kampung seperti Lebai dan Penghulu. Pelaksanaan hukuman berpedoman kepada hukum adat setempat berupa denda, ganti rugi dan hukuman yang paling ringan adalah membayar kasai langgir atau membayar biaya tepung tawar. Balai Bidai juga mempunyai tugas yang sama yaitu mengurusi permasalahan pidana/perdata, tetapi pada tahap yang paling ringan, biasanya membahas soal hukuman tujuh hari.

Dalam merevitalisasi lembaga peradilan agama di Kesultanan Sambas, tidak bisa dipungkiri bahwa dalam menjalankan roda pemerintahan, setidaknya sultan dibantu 15 pembesar negeri lainnya. ${ }^{56}$ Setiap orang memiliki tugas masing-masing berdasarkan jabatan yang diemban, yaitu:

1. Enam orang Mantri Raja (Rijksgrooten) yaitu sebagai pelaksana pemerintahan sehari-hari, terdiri dari patih digelari Pangeran Bendahara (Rijkbestierder), Pangeran Paku Negara sebagai wakil patih, Pangeran Tumenggung, Pangeran Sumalaga yang mengepalai dan memegang urusan keamanan dan kepolisian bersama Pangeran Laksamana.

2. Empat orang Kiyai, yaitu empat orang kepala atau pembesar yang berasal dari daerah-daerah.

3. Empat orang Kaya atau Mantri Ulubalang yang bertindak sebagai utusan atau wakil raja serta mengepalai desa-desa, masing-masing digelari Dato', Lurah, Pembekal dan Pengakal.

4. Seorang Imam Besar (Maharaja Imam) yang mengurusi soal-soal keagamaan.

\footnotetext{
${ }^{56}$ Sunandar, "Sejarah Pengelolaan Baitul Maal di Sambas: Studi Penerapan Hukum Adat dan Hukum Islam di Masa Muhammad Basiuni Imran”, Falsafah III, no. 1 (2017): h. 103.
} 


\section{Peran Sultan Muhammad Mulia Ibrahim Syafiuddin di Kesultanan Sambas 1931-1943 ...}

Penempatan Maharaja Imam dalam Pengadilan Balai Kanon tersebut, dalam struktur Kesultanan Sambas masa pemerintahan Sultan Muhammad Mulia Ibrahim Syafiuddin jelas memperlihatkan bahwa upaya menjadikan hukum yang berlaku adalah bersumber dari tradisi Islam. Maharaja Imam dijadikan sebagai pejabat negara sejak 1823 M masa kepemimpinan Sultan Muhammad Ali Syafiuddin (1813-1826) dengan melantik H. Nuruddin Mustafa sebagai imam kerajaan. Dari keturunan H. Nuruddin Mustafa inilah lahir tiga Maharaja Imam di Kesultanan Sambas yakni Maharaja Imam Muhammad Arif (1873), Maharaja Imam Muhammad Imran (1873-1913) dan Muhammad Basiuni Imran (1913-1976).

Keberadaan Maharaja Imam dan para ulama lainnya memberikan kontribusi besar dalam meningkatkan pemahaman keagamaan masyarakat dan menjadikan Kesultanan Sambas dikenal sebagai pusat pengkajian Islam yang cukup baik pada masa itu sehingga pada masa kolonial ini, jika masyarakat Melayu Sambas bepergian atau mendatangi suatu daerah, mereka dianggap memiliki pengetahuan yang luas tentang agama Islam. Oleh karena itu, dalam hal keagamaan mereka selalu dilibatkan paling tidak sebagai pembaca doa dalam acara selamatan, pernikahan dan kematian. ${ }^{57}$ Berkembangnya aktivitas keagamaan masyarakat berarti Islam di kesultanan sudah semakin eksis bahkan mencapai puncak kegemilangan pada awal abad ke-20.

Maharaja Imam sebagai pimpinan lembaga keagamaan mempunyai tugas khusus di pengadilan agama sehingga ia disebut sebagai qadi, ${ }^{58}$ sekaligus mufti (sebagai pemberi fatwa) Kesultanan Sambas. Salah satu fatwa yang diberikan oleh Basiuni Imran (Maharaja Imam) ialah terkait masalah salat jumat yang kurang dari 40 orang yang pada waktu itu menjadi perdebatan para ulama. ${ }^{59}$ Tugas lain Maharaja Imam adalah sebagai pengawas pada Madrasah Al-Sulthaniyah sejak $1919 \mathrm{M}$ dan mengepalai para pejabat agama. Maharaja Imam memiliki wewenang untuk memilih dan mengajukan para pejabat yang akan diangkat dan dilepaskan dari jabatannya kepada sultan. Hal tersebut menunjukkan bahwa sultan adalah penanggungjawab tertinggi dalam struktur lembaga keagamaan, di bawah sultan terdapat Maharaja Imam yang mengepalai para pejabat agama di bawahnya.

Selanjutnya sebagai pendamping atau wakil Maharaja Imam disebut Imam Maharaja yang mengepalai imam masjid, khatib dan penghulu. Tugas pokok seorang imam adalah menjadi pemimpin salat di masjid, sedangkan khatib bertugas menyampaikan khutbah jumat. Penghulu ${ }^{60}$ bertugas mencatat pernikahan, rujuk dan talak, dalam hal tersebut pada praktiknya penghulu juga dibantu oleh para imam dan

\footnotetext{
${ }^{57}$ Bakran Suni dkk, Laporan Akhir Penelitian Sejarah Melayu Sambas (Pontianak: Lembaga Penelitian UNTAN dan Pemda Sambas, 2007), h. 97.

${ }^{58}$ Qadi adalah seorang hakim yang ditunjuk oleh pemerintah atau govermen atas dasar keahliannya di bidang hukum. Keputusan qadi bersifat mengikat dan final. Ghufron A. Mas'adi, Ensiklopedi Islam (Cet. II; Jakarta: Raja Grafindo Persada, 1999), h. 324.

${ }^{59}$ Anri, Borneo West no.75, 1870. Terkait fatwa yang dikeluarkan dapat di baca dalam kitab Cahaya Suluh yang di tulis oleh Maharaja Imam Muhammad Basiuni Imran. Muhammad Basiuni Imran, Cahaya Suluh: Pada Mendirikan Jum'at Kurang Daripada Empat Puluh (Singapura: Matba' ah al-Ikhwan, 1920), h. 1-10.

${ }^{60}$ Penghulu di Kesultanan Sambas adalah pejabat agama di bawah Maharaja Imam. Lihat Sunandar, Peran Maharaja Imam Muhammad Basiuni Imran dalam Kehidupan Sosial Keagamaan Masyarakat Kerajaan Al-Watzikhoebillah Sambas 1913-1976. Tesis. (Yogyakarta: Pascasarjana UIN Sunan Kalijaga, tidak diterbitkan), h. 96.
} 
khatib. ${ }^{61}$ Sedangkan moedim bertugas mengelola masjid dibawah imam. Bidang lain yang juga menjadi tugas mereka adalah mengumpulkan zakat, infak dan sedekah. Bahkan beberapa orang di antaranya menjadi tenaga pengajar di Madrasah AlSulthaniyah. Kemudian di bawah para pejabat tersebut pada tingkat desa terdapat wakil-wakil imam, khatib dan penghulu yang dibawah mereka terdapat guru mengaji Alquran dan pejabat agama yang disebut lebai. Tugas lebai adalah menangani masalah fardu kifayah. Menurut G. Fredrik yang sebenarnya tugas seorang lebai pada tingkat desa tidak hanya mengurusi masalah jenazah saja, tetapi juga mengurus tentang zakat fitrah, fitrah kelamin dan zakat mal. ${ }^{62}$

Maharaja Imam, Imam Maharaja dan Imam merupakan jawatan tertinggi yang berkedudukan di pusat kerajaan. Sedang khatib dan juru kawin berkedudukan di Bandar atau kampung dan bertanggung jawab langsung kepada Maharaja Imam. Imam Maharaja merupakan wakil dari Maharaja Imam, sedangkan imam dan khatib adalah petugas dalam pelaksanaan salat jumat di masjid-masjid, adapun juru kawin bertugas dalam hal pencatatan perkawinan. ${ }^{63}$

Di masa penjajahan Jepang tidak ada perubahan yang berarti menyangkut peradilan agama. ${ }^{64}$ Keadaan yang sudah ada dilanjutkan sampai Jepang kalah dalam Perang Dunia II. ${ }^{65}$ Dengan Undang-Undang No. 14 Tahun 1942, pemerintah Jepang menetapkan peraturan pengadilan Pemerintah Balatentara Dai-Nippon. Pengadilan itu pada dasarnya adalah lanjutan dari pengadilan-pengadilan yang sudah ada. ${ }^{66}$ Karena situasi yang tidak mendukung, Jepang tidak melaksanakan perubahan besar secara praktis. Keadaan seperti ini bukan berarti Jepang menyetujui susunan badan peradilan, termasuk peradilan agama yang sudah diatur oleh pemerintah kolonial Belanda, tetapi semata-mata karena kesibukannya dalam menghadapi peperangan di mana-mana selama pemerintahannya di Indonesia. ${ }^{67}$ Masa penjajahan Jepang tidak banyak terjadi pembaruan hukum di semua peraturan perundang-undangan dikarenakan peraturan perundang-undangan yang berlaku tidak berlawanan dengan peraturan militer Jepang,

\footnotetext{
${ }^{61}$ Mahchrus Effendy, Riwayat Hidup dan Perjuangan Maharaja Imam Sambas (Jakarta: Dian Kemilau, 1995), h. 30.

${ }^{62}$ Sunandar, Peran Maharaja Imam Muhammad Basiuni Imran dalam Kehidupan Sosial Keagamaan Masyarakat Kerajaan Al-Watzikhoebillah Sambas 1913-1976, h. 146.

${ }^{63}$ Didik M Nur Haris dan Rahimin Affandi Abd Rahim, "Pemikiran Keagamaan Muhammad Basiuni Imran", h. 16. Dalam Kerajaan Melayu, hanya di Kerajaan/Kesultanan Sambas di Kalimantan petugas-petugas penting kerajaan yang menangani Islam digelar 'Maharaja Imam', 'Imam Maharaja', 'Imam', 'Khatib Sidana', dan 'Khatib'. Di antara istilah-istilah itu ada yang telah wujud sejak tahun 1186 H/1772 M. Jawatan Maharaja Imam Sambas berakhir pada tahun 1976 yaitu setelah wafat Maharaja Imam Syeikh Muhammad Basiuni Imran. Bahwa Imam Kerajaan Sambas yang pertama bernama Haji Musthafa Nuruddin yang di lantik oleh Sultan Muhammad Ali Syafiuddin I pada tahun 1186 H/1772 M. Diperkirakan 100 tahun kemudian, tepatnya pada 1289 H/1872 M barulah istilah 'Maharaja Imam' digunakan. Wan Mohd. Shaghir Abdullah, Muhammad Jabir As-Sambasi Khatib Sidana Kerajaan Sambas, http://ulama-nusantara.blogspot.com, diakses pada tanggal 17 Maret 2018, pukul 10.45 wita.

${ }^{64}$ Hanya penyesuian nama menjadi Sooryoo Hoin untuk Pengadilan Agama/Kerapatan Kadi dan Kaikyoo Kooto Hoin untuk Mahkamah Islam Tinggi/Kerapatan Kadi Besar. Lihat Zaini Ahmad Noeh dan Abdul Basit Adnan, Sejarah Singkat Peradilan Agama Islam di Indonesia, h. 21.

${ }^{65}$ Muhammad Daud Ali, Hukum Islam, Pengantar Ilmu Hukum dan Tata Hukum Islam di Indonesia (Cet. III, Jakarta: Raja Grafindo Persada, 1993), h. 209.

${ }^{66}$ R. Tresna, Peradilan di Indonesia dari Abad ke Abad, h. 78.

${ }^{67}$ Sumadi Matrais, "Kemandirian Peradilan Agama dalam Perspektif Undang-Undang Peradilan Agama”, Hukum 15, no. 1 (2008): h. 130.
} 


\section{Peran Sultan Muhammad Mulia Ibrahim Syafiuddin \\ di Kesultanan Sambas 1931-1943 ...}

sehingga aturan hukum yang sebelumnya tetap berlaku namun Jepang menghapus hakhak istimewa orang-orang Belanda dan Eropa lainnya. ${ }^{68}$ Sedikit perubahan perundangundangan yang dilakukan antara lain:

1) Kitab undang-undang hukum perdata, yang awalnya hanya berlaku untuk golongan Eropa dan yang setara diberlakukan juga untuk kaum Cina;

2) Beberapa peraturan militer diselipkan dalam peraturan perundang-undangan pidana yang berlaku.

Di bidang peradilan, pembaharuan pada zaman penjajahan Jepang yang terjadi adalah:

a. Penghapusan pluralisme/dualisme tata peradilan

b. Unifikasi kejaksaan

c. Penghapusan pembedaan polisi kota dan lapangan/pedesaan

d. Pembentukan lembaga pendidikan hukum

e. Pengisian secara besar-besaran jabatan-jabatan administrasi pemerintahan dan hukum dengan rakyat pribumi.

Pada zaman kerajaan/kesultanan Islam Sambas setelah wafatnya Sultan Muhammad Mulia Ibrahim Syafiuddin, lembaga peradilan agama berganti dengan nama Mahkamah Raad Agama, yang menangani penyelesaian sengketa di antara para pencari keadilan. Lembaga ini didirikan dan di awasi langsung oleh pemerintah Kerajaan Islam Sambas oleh pengganti sultan yang selanjutnya. ${ }^{69}$

Sejak Indonesia merdeka, kedudukan hukum diatur di dalam undang-undang dasar (UUD) 1945 pasal 1 ayat 3 perubahan ke-4 yang menyebutkan bahwa "Negara Indonesia adalah Negara Hukum." Ketentuan pasal tersebut merupakan landasan konstitusional bahwa Indonesia adalah negara yang berdasarkan atas hukum, hukum ditempatkan sebagai satu-satunya aturan lain dalam kehidupan bermasyarakat, berbangsa dan bernegara (supremacy law). Pada zaman pemerintahan Swapraja sampai dengan tahun 1952, Mahkamah Raad Agama berubah nama menjadi Mahkamah Balai Agama, yang pengelolaannya dan pengawasannya dipegang oleh pemerintah Swapraja Sambas. Sejak tahun 1952 Mahkamah Balai Agama oleh pemerintah Swapraja Sambas diserahkan pengelolaannya kepada Kementrian Agama. Kemudian atas dasar PP. No. 45 tahun 1957, Penetapan Menteri agama tanggal 6 Maret 1958 No. 4 tahun 1958 secara resmi dibentuklah Pengadilan Agama, dengan nama Pengadilan Agama/Mahkamah Syar'iyah yang mempunyai daerah hukum sama dengan Pengadilan Negeri di Singkawang. ${ }^{70}$

Pengadilan Agama tingkat pertama disebut nama Pengadilan Agama/Mahkamah Syar'iyah sedangkan tingkat banding disebut Pengadilan Agama/Mahkamah Syar'iyah Provinsi. Wewenang pengadilan agama termuat dalam pasal 4 yang berbunyi sebagai berikut: ${ }^{71}$

1. Pengadilan Agama/Mahkamah Syar'iyah memeriksa dan memutuskan perselisihan antara suami istri yang beragama Islam dan segala perkara yang

\footnotetext{
${ }^{68}$ Wawancara dengan Urai Riza Fahmi selaku cucu Sultan Muhammad Syafiuddin II bekerja di Dinas Komunikasi, Budaya dan Pariwisata Kabupaten Sambas sekaligus sebagai sekretaris Keraton Alwazikubillah Sambas, pada tanggal 27 Maret 2018.

${ }^{69}$ Anonim, Sejarah Pengadilan Agama Sambas, http://pa-sambas.go.id/sejarah-pengadilan/ di akses pada tanggal 17 Februari 2018, pukul 16.30 wita.

${ }^{70}$ Anonim, Sejarah Pengadilan Agama Sambas, http://pa-sambas.go.id/sejarah-pengadilan/ di akses pada tanggal 17 Februari 2018, pukul 16.30 wita.

${ }^{71}$ A. Qodri Aziziy, Eklektisisme Hukum Nasional (Yogyakarta: Gama Media, 2002), h. 142.
} 
menurut hukum yang hidup diputus menurut hukum agama Islam yang berkenaan dengan nikah, talak, rujuk, fasakh, nafaqah, mas kawin (mahar), tempat kediaman (maskan), mut'ah dan sebagainya, hadhanah, perkara waris, wal waris, wakaf, hibah, sadaqah, baitul mal dan lain-lain yang berhubungan dengan itu, demikian juga memutuskan perkara perceraian dan mengesahkan bahwa syarat ta'lik sudah berlaku.

2. Pengadilan Agama/Mahkamah Syar'iyah tidak berhak memeriksa perkaraperkara yang tersebut dalam ayat 1, kalau untuk perkara itu berlaku hukum lain daripada hukum agama Islam.

Sejak didirikannya sempai dengan tanggal 1 Desember 1971 kedudukan Pengadilan Agama Sambas berada di kota Sambas, dimana pada saat itu kota Sambas merupakan pusat pemerintahan Kerajaan dan pemerintahan Swapraja Sambas. Kemudian atas dasar pertimbangan bahwa pusat pemerintahan Daerah tingkat II Kabupaten Sambas dialihkan ke kota Singkawang, maka pada tanggal 6 Desember 1971 dengan inisiatif dari Ketua Pengadilan Agama pada waktu itu Pengadilan Agama juga dipindahkan ke kota Singkawang. Gedung Pengadilan Agama Sambas di Singkawang sejak tahun 1971 sampai dengan tahun 1980 menempati gedung milik PEMDA Tk. II. Sambas bersama-sama dengan Kantor Departemen Agama dan sejak tanggal 17 Maret 1980 Pengadilan Agama Sambas telah memiliki Gedung Pengadilan Agama sendiri yang dana pembangunannya dari APBN Tahun 1979/1980. Selanjutnya karena adanya pemekaran wilayah Kabupaten Sambas menjadi 3 wilayah yaitu Kota Singkawang, Kabupaten Sambas, dan Kabupaten Bengkayang, maka pada tahun 2001 kedudukan Pengadilan Agama Sambas yang semula berada di Singkawang dipindah ke ibukota Kabupaten Sambas yaitu di Kota Sambas.

Sebelum pengadilan negeri Sambas berdiri, seluruh proses penyelesaian perkara persidangan dilaksanakan di pengadilan negeri Singkawang karena pada saat itu wilayah hukum di pengadilan negeri singkawang masih meliputi wilayah pemerintahan Tk. II Kabupaten Sambas. ${ }^{72}$ Hingga pada tahun 1999 wilayah Sambas dimekarkan menjadi Pemerintah Daerah Kabupaten Sambas, namun proses perkara persidangan saat itu masih dilangsungkan di pengadilan negeri Singkawang hingga pada tahun 2007, pengadilan negeri Sambas resmi berdiri dengan wilayah hukum daerah pemerintahan Kabupaten Sambas.

Dasar hukum pembentukan pengadilan negeri Sambas diatur dalam Keputusan Presiden Nomor 2 Tahun 2007 tentang Pembentukan Pengadilan Negeri Sambas dan Pengadilan Negeri Bengkayang yang ditetapkan di Jakarta pada tanggal 07 Januari 2007 dan ditandatangani oleh Presiden Republik Indonesia, DR. H. Susilo Bambang Yudhoyono. Pengadilan Negeri Sambas adalah Pengadilan Negeri Kelas II yang dibangun dari dana APBN DIPA tahun 2006 dan diresmikan pada tanggal 31 Juli 2007 oleh Ketua Mahkamah Agung Republik Indonesia, Prof. Dr. H. Bagir Manan, SH., M.S.L. Sejak itu pula secara resmi Pengadilan Negeri Sambas beroperasi hingga saat ini.

\section{IV.PENUTUP}

\footnotetext{
${ }^{72}$ Sayyid Abdullah Alqadrie, Kisah Teladan Islami, http://kesultanankadriah.blogspot.com, diakses pada tanggal 03 April 2017, pukul 14.30 wib.
} 
Sultan Muhammad Mulia Ibrahim Syafiuddin merevitalisasi peradilan khusus untuk golongan pribumi tahun 1936. Dibentuk lembaga Peradilan Khusus untuk golongan pribumi di Sambas, melengkapi pengadilan agama yang sudah berlaku turun temurun. Pengadilan Negeri yang sebelumnya disebut Landraad untuk golongan pribumi diganti namanya dengan Pengadilan Balai Kanon. Pengadilan setempat yang sebelumnya disebut Magistraat untuk golongan pribumi diganti dengan Pengadilan Balai Raja. Pengadilan Adat diganti namanya dengan Pengadilan Balai Bidai. Pada masa penjajahan Jepang tidak banyak terjadi pembaruan hukum di semua peraturan perundang-undangan dikarenakan peraturan perundang-undangan yang berlaku tidak berlawanan dengan peraturan militer Jepang, sehingga aturan hukum yang sebelumnya tetap berlaku namun Jepang menghapus hak-hak istimewa orang-orang Belanda dan Eropa lainnya.

Penempatan Maharaja Imam dalam pengadilan balai kanon tersebut, dalam struktur Kesultanan Sambas masa pemerintahan Sultan Muhammad Mulia Ibrahim Syafiuddin jelas memperlihatkan bahwa upaya menjadikan hukum yang berlaku adalah bersumber dari tradisi Islam. Maharaja Imam dijadikan sebagai pejabat negara sejak 1823 M masa kepemimpinan Sultan Muhammad Ali Syafiuddin (1813-1826). Peran sentral Maharaja Imam adalah yang berhubungan dengan kehidupan agama di Kesultanan Sambas. Kehidupan sosial keagamaan, dikendalikan oleh elit pemerintah, yaitu melalui lembaga resmi agama.

\section{DAFTAR PUSTAKA}

\section{Arsip}

ANRI. Borneo West No.72, 1867.

Arsip Silsilah Kesultanan Sambas No. 28.

Borneo Simboen Pontianak, Tahun ke II, No. 135, 1 Juli 1944.

Manuskrip Kisah Negeri Sambas 1568-1944, 10 Juli 1991, No. 31.

Manuskrip Silsilah Sultan Muhammad Syafiuddin (Sambas) tahun 1903, No. 40.

\section{Buku, Jurnal}

Achlis. Studi Perilaku dan Lingkungan Sosial Manusia. Bandung: Koperasi Mahasiswa Sekolah Tinggi Kesejahteraan Sosial, 1993.

Alatas, Syed Hussein. Sosiologi Korupsi Sebuah Penjelajahan dengan Data Kontemporer. Jakarta: LP3ES, 1986.

Ali, Muhammad Daud. Hukum Islam, Pengantar Ilmu Hukum dan Tata Hukum Islam di Indonesia. Cet. III, Jakarta: Raja Grafindo Persada, 1993.

Anri, Borneo West no.75, 1870.

Aziziy. A Qodri. Eklektisisme Hukum Nasional. Yogyakarta: Gama Media, 2002.

Bisri, Cik Hasan. Peradilan Agama di Indonesia. Cet. IV; Jakarta: PT Raja Grafindo Persada, 2003.

Burke, Peter. History and Social Theory diterjemahkan oleh Mestika Zed dan Zulfahmi dengan judul Sejarah dan Teori Sosial. Jakarta: Yayasan Obor Indonesia, 2001. 
Djalil, A Basiq. Peradilan Agama di Indonesia. Jakarta: Kencana, 2006.

Effendy, Mahchrus. Riwayat Hidup dan Perjuangan Maharaja Imam Sambas. Jakarta: Dian Kemilau, 1995.

Halim, Abdul. Peradilan Agama dalam Politik Hukum di Indonesia. Jakarta: Raja Grafindo Persada, 2000.

Hamka. Sejarah Umat Islam Jilid III. Jakarta: Bulan Bintang, 198.

Haris, Didik M. Nur dan Rahimin Affandi Abd Rahim. "Pemikiran Keagamaan Muhammad Basiuni Imran", Al-Banjari 16, no. 2 (2017): h. 1-25.

Imran, Muhammad Basiuni. Cahaya Suluh: Pada Mendirikan Jum'at Kurang Daripada Empat Puluh. Singapura: Matba'ah al-Ikhwan, 1920.

Koentjaraningrat. Kebudayaan, Mentalitas dan Pembangunan. Jakarta: PT Gramedia Pustaka Utama, 1994.

Lubis, Sulaikin. Hukum Acara Perdata Peradilan Agama di Indonesia. Jakarta: Kencana, 2006.

Mahrus, Erwin, Rosadi Jamani dan Edy Kusnan Hadi. Shayk Ahmad Khatib Sambas: Sufi dan Ulama Besar Dikenal Dunia (1803-1875). Pontianak: UNTAN Press, 2003.

Mas'adi, Ghufron A. Ensiklopedi Islam. Cet. II; Jakarta: Raja Grafindo Persada, 1999.

Matrais, Sumadi. "Kemandirian Peradilan Agama dalam Perspektif Undang-Undang Peradilan Agama", Hukum 15, no. 1 (2008): h. 121-144.

Matrais, Sumadi. "Kemandirian Peradilan Agama dalam Perspektif Undang-Undang Peradilan Agama", Hukum 15, no. 1 (2008): h. 124.

Muhammad, Rusli. "Rekonstruksi Lembaga Pengadilan Menuju Indonesia Baru", UNISIA, no. 53 (2004): h. 242-254.

Munawwir, Ahmad Warson. Kamus Al-Munawwir Indonesia-Arab Terlengkap. Surabaya: Pustaka Progressif, 2007.

Musa, Pabali H. Sejarah Kesultanan Sambas Kalimantan Barat: Kajian Naskah Asal Raja-Raja dan Silsilah Raja Sambas. Pontianak: STAIN Pontianak Press, 2003.

Noeh, Zaini Ahmad dan Abdul Basit Adnan. Sejarah Singkat Pengadilan Agama Islam di Indonesia. Surabaya: Bina Ilmu, 1980.

Noeh, Zaini Ahmad dan Abdul Basit Adnan. Sejarah Singkat Peradilan Agama Islam di Indonesia. Surabaya: Bina Ilmu, 1983.

Nurcahyani, Lisyawati dkk. Sejarah Kerajaan Sambas. Pontianak: Direktorat Sejarah dan Nilai Tradisional. Proyek Inventarisasi dan Dokumentasi Sejarah Nasional, 1995.

Projodikoro, R Wirjono. Hukum Acara Perdata di Indonesia. Bandung: Sumur Bandung, 1992.

R, Ahmad. "Peradilan Agama di Indonesia", Yudisia 6, no. 2 (2015): h. 311-339. 
Rahim, Husni. Sistem Otoritas dan Administrasi: Studi tentang Pejabat Agama Masa Kesultanan dan Kolonial di Palembang. Jakarta: Logos, 1998.

Rahman, Ansar dkk. Kabupaten Sambas: Sejarah Kesultanan dan Pemerintah Daerah. Sambas: Dinas Pariwisata PEMDA Kabupaten Sambas, 2001.

Reading, Hugo F. Social Sciences-Dictionaries penerjemah Sahat Simamora dengan judul Kamus Ilmu-Ilmu Sosial. Cet. I; Jakarta: Rajawali, 1986.

RI, Kementerian Agama. Al-Qur'an dan Terjemahnya. Bandung: Semesta Al-Qur'an, 2013.

Rofiq, Ahmad. Hukum Islam di Indonesia. Cet. IV; Jakarta: PT Raja Grafindo Persada, 2000.

Salim, Moh. Haitami dkk. "Sejarah Kerajaan Sambas Kalimantan Barat". Laporan Penelitian. Pusat Penelitian dan Pengabdian pada Masyarakat (P3M) STAIN, Pontianak, 2010.

Soekanto, Soerjono. Sosiologi Suatu Pengantar. Jakarta: PT. Raja Grafindo Persada, 1995.

Soekanto, Soerjono. Teori Peranan. Jakarta: Bumi Aksara, 2002.

Soyomukti, Nurani. Pengantar Sosiologi: Dasar Analisis, Teori dan Pendekatan Menuju Analisis Masalah-Masalah Sosial, Perubahan Sosial dan Kajian-Kajian Strategis. Yogyakarta: Ar-Ruzz Media, 2010.

Subroto K. "Negara-Negara Islam di Kalimantan 1425-1905 M", (Laporan), Syamina, edisi 18 Desember 2017.

Sunandar. Peran Maharaja Imam Muhammad Basiuni Imran dalam Kehidupan Sosial Keagamaan Masyarakat Kerajaan Al-Watzikhoebillah Sambas 1913-1976. Tesis. Yogyakarta: Pascasarjana UIN Sunan Kalijaga, tidak diterbitkan.

Suni, Bakran dkk. Laporan Akhir Penelitian Sejarah Melayu Sambas. Pontianak: Lembaga Penelitian UNTAN dan Pemda Sambas, 2007.

Tim Penyusun Kamus Pusat Pembinaan dan Pengembangan Bahasa. Kamus Besar Bahasa Indonesia. Cet. VII; Jakarta: Balai Pustaka, 1996.

Tjandrasasmita, Uka. Sejarah Nasional Indonesia (Jilid 3). Jakarta: Depdikbud, 1982.

Tresna, R. Peradilan di Indonesia dari Abad ke Abad. Jakarta: Pradnya Paramita, 1978.

Umberan, Musni dkk. Sejarah Kerajaan Sambas. Pontianak: Depdikbud, 1995.

Usman, Syafaruddin MHD. Sambas Merajut Kisah Menenun Sejarah. Pontianak: tt, 2011.

Wiratraman, Herlambang P. "Perkembangan Politik Hukum Peradilan Adat", Mimbar Hukum 30, no. 3 (2018): h. 490-505. 


\section{Sumber Internet}

Abdullah, Wan Mohd Shaghir. Muhammad Jabir As-Sambasi Khatib Sidana Kerajaan Sambas, http://ulama-nusantara.blogspot.com, diakses pada tanggal 17 Maret 2018, pukul 10.45 wita.

Alqadrie, Sayyid Abdullah. Kisah Teladan Islami, http://kesultanankadriah.blogspot.com, diakses pada tanggal 03 April 2017, pukul 14.30 wita.

Anonim. Pengertian Peradilan dalam Perspektif Hukum Islam, http://WWW.informasiahli.com, diakses pada tanggal 19 Maret 2018, pukul 20.38 wita.

Anonim. Sejarah Pengadilan Agama Sambas, http://pa-sambas.go.id/sejarahpengadilan/di akses pada tanggal 17 Februari 2018, pukul 16.30 wita.

Marzuki. Peradilan Agama Sebagai Institusi Penegak Hukum Islam di Indonesia, http://staffnew.uny.ac.id/ di akses pada tanggal 01 Februari 2019, pukul 13.18 wita.

P, Endah. Sejarah Peradilan Agama, https://badilag.mahkamahagung.go.id di akses pada tanggal 24 Maret 2018, pukul 19.58 wita.

Sukri, Muhammad. Sejarah Peradilan Agama di Indonesia (Pendekatan Yuridis), https://WWW.google.com-sejarah-peradilan-agama-di-indonesia.pdf, diakses pada tanggal 31 Januari 2019, pukul 13.15 wita.

Suwargana, Asep Iman. Sejarah Peradilan Agama di Indonesia dalam http://asepimansuwargana.blogspot.com di akses pada tanggal 31 Januari 2019, pukul 14.00 wita.

\section{Sumber Wawancara}

Wawancara dengan Pangeran Ratu Muhammad Tarhan, pada tanggal 28 Maret 2018.

Wawancara dengan Urai Riza Fahmi, pada tanggal 27 Maret 2018. 